\title{
Ahmed b. Hanbel ve Tayâlisî Müsnedlerinde Rivayeti Bulunan Kadın Sahabîlerin Rivayetlerinin Değerlendirilmesi*
}

Araștırma makalesi / Research article

\author{
Sehal D. Varlık Kotan** \\ The Evaluation of Women Companions with Narrations in Ahmed b. Hanbel \\ and Tayâlisî's Musnads
}

Citation/@: Kotan, Sehal D. Varlık, (2020). The Evaluation of Women Companions with Narrations in Ahmed b. Hanbel and Tayâlisî's Musnads, Milel ve Nihal, 17 (1), 137-165.

Abstract: The science of hadith, one of the basic Islamic sciences, is a branch in which women contribute significantly. Women's contribution to the hadith science is most visible in the companions period. However, the subjects such as the ratio of the narrations of women companions in the corpus of narrations, which topics they contain, which of the women companions' number of narrations increased, and the reasons for this increase have not been studied in detail. Yet, the narrations of women companions are the primary source in finding the correct answers to questions like what the Prophet's (pbuh) conduct was like while communicating with women, what kind of opportunities he tried to offer to them in social life, what kind of warnings he made, and in which topics he encouraged them, etc. Besides, it is possible to see the role of women companions throughout the hadith science, to find factors that restrict or facilitate this role, by examining their narrations. The number of non-repetitive narrations must be determined to find out the number of narrations that differ in terms of sanad and statements, the increased number of narrations as a result of counting them as different narrations, and how many narrations it adds up to in reality. In this study, which was carried out to contribute to the recognition of the narrations of women companions, to determine the repetitions, and

* Makale, yazarın Kadın "Sahabîlerin Rivayetlerinin Değerlendirilmesi" (Ankara: Ankara Üniversitesi, 2019) başlıklı doktora tezine dayanarak hazırlanmıştır. Makalede yapılan değerlendirmelerin geneli, birden fazla veriye dayanır ve her biri dipnotla gösterilse makale formatına sığmayacaktır. İhtiyaç duyulan yerlerde teze müracaat edilmelidir.

** Dr., DİB İstanbul Beykoz Müftülüğü ADRB Vaizi. [sehaldeniz@hotmail.com] ORCID: 0000-0002-3247-7490. 
to evaluate them together; the narrations of 105 women companions who have narrations in the two selected sources are examined and the numbers of repetitions are determined.

Keywords: Hadith, Women Companions, Narration, Narrator, Non-repetitive Narration, Narration Topics.

Atıf/C: Kotan, Sehal D. Varlık, (2020). Ahmed b. Hanbel ve Tayâlisî Müsnedlerinde Rivayeti Bulunan Kadın Sahabîlerin Rivayetlerinin Değerlendirilmesi, Milel ve Nihal, 17 (1), 137-165.

Öz: Temel İslam İlimlerinden hadis ilmi, kadınların dikkate değer oranda katkıda bulundukları bir ilim dalıdır. Sahabe dönemi ise kadınların hadis ilmine katkısının en görünür olduğu dönemdir. Hâlbuki rivayet külliyatı içinde kadın sahabîlerin rivayetlerinin ne oranda yer tuttuğu, hangi konuları içerdiği, kadın sahabîlerden kimlerin rivayet sayısının arttığı ve bu artışın sebepleri gibi konular ayrıntılı çalışılmamıştır. Oysaki Hz. Peygamber'in (s) kadınlarla iletişiminde davranış şekli nasıldı, sosyal hayatta onlara nasıl imkânlar sunmaya çalışmıştı, ne gibi uyarılar yapmış, hangi konularda teşvik etmişti vb. soruların doğru cevaplarını bulmakta kadın sahabîlerin rivayetleri birincil kaynaktır. Ayrıca hadis ilmi genelinde kadın sahabîlerin rolünü görebilmek, bu rolü kısıtlayan veya kolaylaştıran etkenleri bulabilmekte onların rivayetlerini incelemekle mümkündür. Sened ve lafızlarında farkııık bulunan rivayetlerin, farklı rivayet sayılması ile kabaran rivayet sayılarının, gerçekte kaç rivayete tekabül ettiğinin bulunması içinse tekrarsız rivayet sayıları tespit edilmelidir. Kadın sahabîlerin rivayetlerinin tanınmasına, tekrarlarının tespitine, bir arada değerlendirilmesine katkıda bulunmak amacıyla yapılan bu çalışmada, seçilen iki kaynakta rivayeti bulunan 105 kadın sahabînin rivayetleri incelenmekte, tekrarsız rivayet sayıları tespit edilmektedir.

Anahtar Kelimeler: Hadis, Kadın Sahabî, Rivayet, Râvi, Tekrarsız Rivayet, Rivayet Konuları.

\section{Giriş}

Vahiy ve Allah Resûlü liderliğinde şekillenen toplumda yaşayan kadınların şahitliğine dayalı bilgileri kaydetmenin ${ }^{1}$ ötesine geçip anlamlandırmak, İslam'da kadının konumuna dair meselelerde Hz. Peygamber'in örnekliğine dayalı çözümler üretebilmek için gereklidir. Gerçekte Allah Resûlü'nün kadınlarla diyaloğu nasıldır, sosyal hayatta onlara hangi imkânları sunmuş, nasıl bir eş, akraba olmuş, ne gibi uyarılar yapmıştır, onları hangi konularda teşvik etmiştir vb.

1 Temel kaynaklarda yer alan kadın sahabe kaynaklı rivayetler, kayıt olarak kabul edilebilir. 
Ahmed b. Hanbel ve Tayâlisî Müsned'lerinde Rivayeti Bulunan Kadın Sahabîlerin... soruların doğru cevaplarını bulmak için de kadın sahabîlerden nakledilen rivayetler, önemli bir kaynaktır.

Kadın sahabîlerin rivayetleri, günümüze kadar kapsamlı bir çalışmaya konu edilmese de bazı eserlerde konuya dair bazı bilgiler zikredilmiştir. Mesela Akram Nadwî'nin muhaddis kadınlara hasrettiği eserinde, İslam'da ilim-hadis öğrenme ve öğretmede kadınerkek farkı olmadığını vurgulayan ilk bölümlerde, örnekler çoğunlukla kadın sahabîlerin rivayetlerinden verilmiş ve bir başlık da kadın sahabe ve öğrencilerine ayrılmıştır. ${ }^{2}$ Benzer şekilde Asme Sayeed de Women and the Transmission of Religious Knowledge in Islam adlı kitabın ilk bölümünü, kadın sahabeye ayırmıştır. ${ }^{3}$ Bu çalışmada kadınların ilk dönem hadis rivayetinde etkili olduklarına dikkat çekilerek rivayetlerinden örnekler verilmiş, bazı kadın sahabîlerin rivayet sayılarına değinilmiş olsa da bu ve benzeri çalışmalar ${ }^{4}$ konuyu kapsamaktan uzaktır.

Şimdiye kadar yapılan çalışmalarda, bu çalışmada olduğu gibi, kadın sahabîlerin rivayetlerinin müsned türü eserlerde ne oranda yer tuttuğunu, tekrar oralarının ne olduğunu, konularının neler olduğunu, Hz. Peygamber'in kadınlarla diyaloğunda uyduğu hangi ahlaki prensipleri açığa çıkardığını birlikte değerlendireni yoktur.

Çalışma konusunun "Kadın Sahabîlerin Rivayetleri" olarak seçilmesi, kaynakları sınırlamayı kaçınılmaz kılar. Zira Kütüb-i Tis' $a$ 'daki Hz. Âişe'nin rivayetlerinin sayısı, 5 bin 965'tir. ${ }^{5}$ Sadece Hz. Peygamberin eşlerinden Kütüb-i Tis' $a$ ' da yer alan rivayetler ise 7 bin 125 adettir. ${ }^{6}$ Bir çalışmada bu sayıda rivayeti, üzerine diğer kadın sahabe rivayetlerini de ekleyerek çalışmak, sınırları zorlayıcıdır. Konunun genişliği, temel kaynak belirlemeyi zorunluluk hâline

2 Mohammad Akram Nadwi, al-Muhaddithat: The Women Scholars in Islam (Oxford: Interface, 2007).

3 Asma Sayeed, Women and the Transmission of Religious Knowledge in Islam (Cambridge: Cambridge University Press, 2013), 19-62.

4 Hamza Muhammed Emîn, Cühûdü'l-mer'e fî rivâyeti'l-hadîsi'l-nebeviyyi'l-şerîfi fîllkurûni'l-selâseti'l-ûlâ (Ürdün: Câmi'atu Âl el-Beyt, 1999); Afâf Abdülgafûr Hamîd, "Cühûdü'l-mer'e fî neşr'il-hadîsi ve ulûmuhu”, Mecelletü Câmi'a'ti'l-ummü'l-kurâ li ulûmi'l-şer'iyye 19/42 (2007): 230-270; Hatice Kurt, Sahab̂̂ Hanımlar ve Hadis Ilmi, (Sakarya: Sakarya Üniversitesi, 2001) Mehmet Eren, "Kadınların Hadis İlmine Katkıları", Ankara Üniversitesi İlahiyat Fakültesi Dergisi 44/1 (2003): 83-110 ve diğerleri.

5 Ali Budak, "Muhtevaları Açısından Ezvâc-1 Tâhirât'ın Rivayetleri”, Dicle Üniversitesi İlahiyat Fakültesi Dergisi 13/2 (2011): 46-48.

6 Budak, "Muhtevaları Açısından Ezvâc-1 Tâhirât'ın Rivayetleri", 46. 
getirir. Konu sahabî râvisine dayandığından kaynakları müsned türünden seçmek uygundur. Bugün elimizdeki basılı müsnedlerin en kapsamlısı, Ahmed b. Hanbel'in (ö. 241/855) Müsnei'idirr ve çalışmamızın birinci kaynağıdır. Bu eserdeki rivayetler incelendiğinde, rivayet külliyatının önemli bir kısmı değerlendirilmiş olacaktır. İlk dönem kaynaklarından birini çalışmaya dâhil etmenin zenginlik sağlayacağı düşünülürse basılı müsnedler içinde en eski kabul edilen Tayâlisî́n nin (ö. 204/819) Müsned'idir ${ }^{8}$ ve çalışmamızın ikinci kaynağıdır.

Seçilen iki kaynağın kadın sahabîlerin rivayetlerine ayrılmış kısmında, mübhemlerle birlikte 105 kadın sahabenin yaklaşık 3 bin 800 rivayeti, tekrarlı şekilde yer almaktadır. ${ }^{9} \mathrm{Bu}$ rivayetlerin her biri çalışma verilerine dahildir. Âişe ve Ümmü Seleme validelerimiz d1şındaki her kadın sahabînin, farklı kaynaklardaki rivayetlerinden ulaşılanlar da çalışma kapsamındadır.

\section{Kadın Sahabîlerin Hadis İlmine Katkısı}

Tarih boyunca İslami ilimlerde kadınların ilmî faaliyetlerinin en fazla Hadis İlminde görüldüğü, bu faaliyetin Hz. Peygamber döneminde başlayıp asırlar boyu devam ettiği dile getirilmiştir. ${ }^{10}$ Fakat kadınların bu ilimde en etkin rolü, sahabe ve tâbiîn neslinde gösterebildiği, zaman içinde bu rolün azaldığı da bilinmektedir. ${ }^{11}$ Sahabe tabakâtı ile ricâl kitabı türü eserlerdeki tercümelerin kadın-erkek oranına bakmak bile kadınlar hakkında kaydedilen bilgilerin zamanla hangi oranda azaldığını gösterir. Mesela tabakât kitaplarından İbn Hacer'in (ö. 852/1449) el-İsâbe'sinde kadın tercümelerinin

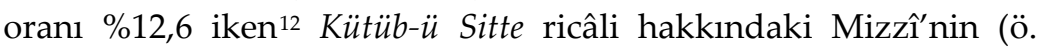

7 M. Yaşar Kandemir, "el-Müsned", DİA (Ankara: TDV Yayınları, 2006) c. XXXII, 104.

8 Zekeriyya Tüfekçioğlu, Hadis Edebiyatında Müsnedler (Hicrî İlk Üç Asır), (İstanbul: Marmara Üniversitesi, 2012), 64.

9 Ahmed b. Hanbel, Ebû Abdullah Ahmed b. Muhammed b. Hanbel eş-Şeybânî elMervezî, el-Kütübü's-sitte ve şürûhuha: Müsnedu Ahmed b. Hanbel (İstanbul: Çağr1 Yayınları, 2. baskı, 1982), c. XXXIII.

10 M. Tayyib Okiç, İslâmiyette Kadın Öğretimi (Ankara: DİB Yayınları, 1984), 51-52.

11 Nusret Bolelli, Kadınların Hadis İlmindeki Yeri (İstanbul: Marmara Üniversitesi İlahiyat Fakültesi Yayınları, 1998) 46-194.

12 İbn Hacer, Ebü'l-Fazl Şihâbüddîn Ahmed b. Alî b. Muhammed b. Hacer el-Askalânî, el-ísâbe fì Temyîzi's-Sahâbe (Kahire: Mektebetü't-Ticariyyeti'l-Kübrâ, 1939).

Eserde yer alan 12 bin 300 tercümenin 1 bin 551'i kadınlara dairdir. 
Ahmed b. Hanbel ve Tayâlisî Müsned'lerinde Rivayeti Bulunan Kadın Sahabîlerin... 742/1341) Tehzîbu'l-Kemâl'inde bu oran \%3,4'e düşmüştür. ${ }^{13}$ Kadın sahabîlerin hadis ilmine nicel katkısını görmekte temel hadis kaynaklarında onların rivayetlerinin ne oranda yer aldığı da önemli bir veridir. Ahmed b. Hanbel'in Müsned'inde bu oran yaklaşık \%12,6 iken Tayâlisî'nin Müsned'inde \%10,4, Taberânî'nin el-Mu'cemü'lKebîr' inde ise \%12'dir. ${ }^{14}$ Müsned türü eserlerde rivayetlerinin oranı genelde \%10'un altına düşmez. Kadınların hadis ilmine katkısının en kolay görülebildiği dönem sahabe dönemidir.

Bu katkıda, Hz. Peygamber'in eşlerinin payı büyüktür. Kadın sahabîlerden gelen rivayetlerinin çoğu, onlardan nakledilmektedir. ${ }^{15}$ Allah Resûlü'nün eşlerini, toplum hayatının merkezinde tutması, onlara yaşanan olaylardan haberdar olma ve ilimlerini arttırma imkânı sağlamıştır. Ayrıca o (s), eşlerine her günün belli vakitlerini ayırmış, onların eğitimleriyle ilgilenmiş, sorularını cevaplamış, yolculuklarında mutlaka onlardan birini yanına almıştır.

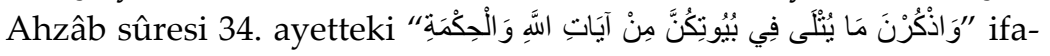
desi, Hz. Peygamberin eşlerine evlerinde okunan Allah'ın ayetlerini ve hikmeti -yani bir görüşe göre sünneti ${ }^{16}$ ve Hz. Peygamber'in sözlerini ${ }^{17}$ - düşünmeyi, anmayı, hatırda tutmayı emreder. Onlar da üzerlerine yüklenen bu vazifeyi, konumlarının avantajılla kavuştukları bilgi ve birikimi imkânları ölçüsünde aktararak yerine getirmişlerdir. Öyle ki hadis ilmine katkısı olan kadın sahabe denildiğinde, ilk akla gelenler onlardır. Kadın sahabenin rivayetleri içinde Hz. Peygamberin eşlerinden gelenler hem sayısal çokluk hem de içerik çeşitliliği açısından özel bir yer tutar. Bu çalışmada ulaşılan kadınlardan gelen toplam rivayet $1.250^{18}$ civarıyken, Peygamber eşlerinden: Âişe bnt. Ebî Bekir'in 690, Ümmü Seleme'in 100, Meymûne

13 Mizzî, Ebü'l-Haccâc Cemâlüddîn Yûsuf b. Abdurrahman b. Yûsuf, Tehzîbü'lKemâl fì Esmâî'r-Ricâl, thk. Beşşâr Avvâd Ma'rûf (Beyrut: Müessesetü'r-Risâle, 1992). Eserde yer alan 7 bin 779 tercümenin 266'sı kadınlara dairdir.

14 Taberânî, Ebû Kâsım Süleyman b. Ahmed, el-Mu'cemü'l-Kebîr, thk. Ebû Muhammed Esyûtî (Beyrut, Dâru'l-Kütübi'l-İlmiyye, 2007), c. IX-X. Eserdeki yaklaşık 21.000 rivayetten 2.550 'si kadın sahabedendir

15 İ. Muhammed Cemel, Câmi'u mesânidi'n-nisâ' ve zikrihinne ve ahvâlihinne (Kahire: Dâru'l-Misriyyeti'l-Lübnaniyye, 1992), 16.

16 İbn Kesîr, Ebü'l-Fidâ İmâdüddîn İsmâil b. Ömer, Tefsîru'l-Kur'âni'l-Azîm: Tefsîru İbn Kesîr (Beyrut: Dâru'l-Endelüs, 1966), c. V, 459.

17 Fahreddîn er-Râzî, Ebû Abdullah Fahreddîn Muhammed b. Ömer, et-Tefsîru'lkebîr: Mefâtîhu'l-gayb (Beyrut: Dâru ihyâi't-türâsi'l-Arabî, 1934), c. XV,210.

18 Hz. Âişe ve Hz. Ümmü Seleme haricindeki kişilerin diğer kaynaklarda bulunan rivayetlerinden ulaşılıp çalışmaya eklenen 250 kadar rivayet vardır. 
bnt. Hâris'in 45, Hafsa bnt. Ömer'in 27 ve Ümmü Habîbe'in 26 rivayeti vardır. Temel iki kaynakta tekrarsız tespit edilen 1000 rivayetin yaklaşık 750'si de Hz. Peygamber'in eşlerindendir. ${ }^{19}$ Hatta Hz. Peygamber'in çok eşliliğinin sebeplerinden birinin, kadınları eğitmek üzere öğretmen yetiştirme ihtiyacı olabileceği söylenilmiştir. ${ }^{20}$

Peygamber eşlerinden sonra rivayet ilminde temayüz ettiği görülen kadınlardan bazıları; Esmâ bnt. Ebî Bekir, Ümmü Hânî, Esmâ bnt. Umeys, Ümmü Fazl gibi Allah Resûlü'nün akraba ve hısımlardır. Bazıları ise Esmâ bnt. Yezîd, Ümmü Atıyye ve Ümmü Süleym gibi ilk ve ileri gelen Müslümanlardandır ve bu özellikleriyle Allah Resûlü'nden iltifat ve yakınlık görmüşlerdir. Ümmü Eymen ve kızı Meymûne bnt. Sa'd ${ }^{21}$ ile Selmâ Ümmü Râfi', Hz. Peygamber'in âzatlılarıdır. Şifâ bnt. Abdullah ise ilk hicret eden kadınlar içinde ilmi ve faziletiyle tanınan bir kadındır, erken dönem sayılacak hicrî 20-30 yıllarındaki vefatına ${ }^{22}$ rağmen 10'un üzerinde rivayeti olan 19 kadın sahabe arasına girmiştir. Bu kadın sahabîlerin her birinin bir şekilde Allah Resûlü'nün yakın çevresinden olması da rivayet sürecinin doğal bir seyir takip ettiğini gösterir.

Çalışma kapsamında tekrarsız rivayetleri sayılan kadın sahabeden, rivayeti beş ve beşten fazla olan kadınların sayısı 32'dir. Rivayeti iki, üç ve dört olanlarsa 22 kişidir. Kalan 51 kadın sahabenin tek rivayeti vardır. Mübhemler hariç, 101 kadın sahabenin yarısının rivayeti tektir ve çoğunlukla kaynaklarda isimlerinin geçmesinin sebebi bu rivayettir. Bu grubun rivayetleri, genelde aile içinde nakledilmiştir. Hadis ilmi olmasa muhtemelen isimleri unutulacak bu kadınların râvileri ve bunlar arasında da özellikle kadınlar, çoğunlukla meçhul sayılmıştır. Klasik usülde râvinin meçhul olması senedin ve dolayısıyla rivayetin zayıf görülme sebebidir. Oysa Hz. Peygamber'in yakın çevresinde bulunmayan, bir şekilde ondan gördüğü veya duyduğu tek bir şeyi aktarabilen bu kadınların râvilerinin tanınmaması, doğaldır. Bu yüzden kadın sahabîlerden hadisi rivayet eden tâbiûnun meçhul olması, rivayeti zayıf veya merdûd kabul etmek için yeterli görülmemelidir. Bilakis kaynaklarımızın iç

19 Her bir eşin rivayeti ayrı tespit edildiği, Âişe ve Ümmü Seleme'ninkiler hariç, farklı eşlerin rivayetleri arasındaki tekrarlar tespit edilmediği için yaklaşık bir sayı verildi.

20 M. Mahfuz Söylemez, "Hz. Peygamber'in Bir Günü Üzerine”, İslâmî İlimler Dergisi 1/1 (2006): 81.

21 Mizzî, Kemâl, I, 208.

22 İbn Sa'd, Tabakât, VIII, 268. 
Ahmed b. Hanbel ve Tayâlisî Müsned'lerinde Rivayeti Bulunan Kadın Sahabîlerin...

kritiği açısından bu veri olumludur ve sürecin doğal işlediğine işaret eder.

Kadın sahabîlerin rivayetlerini nicelik açısından değerlendirirken gerçeğe yakın bir değerlendirme için tekrarsız rivayet sayılarına bakılmalıdır. Zira tekrarlar, eldeki bilginin sayısal değerini birkaç kat arttırarak yansitır.

\section{Kadın Sahabîlerin Tekrarsız Rivayet Sayıları ve Bu Sayılara Göre Sıralamaları}

Temel hadis kaynaklarındaki rivayetlerin sayıca çokluğu sebebiyle orijinalliklerini sorgulayanlar çıkabilmektedir. Oysa rivayet sayılarının artmasında tekrarların etkisi bilinir. Tekrarsız rivayet adetlerinin tespitiyle, rivayetlerin sayısal çokluğu yönünde yapılan eleştirilerin isabeti açığa çıkacaktır. Bunun yanı sıra, kadınlardan gelen bilgilerin gerçek miktarı görülebilecektir. Çalışmada, incelenen her bir kadın sahabînin tekrarsız rivayet sayısı tespit edilmektedir. Tekrarsız rivayetle kast edilen; aynı durum ve olaydan bahsettiği izlenimi veren rivayetlerin, sened ve lafızları farklı olsa bile bir araya getirilip tek rivayet sayılmasıdır.

Çalışmamızda incelenen 3 bin 800 rivayetin tekrarsızda 1000 civarında olduğu ve dörtte üçe yakın tekrarın bulunduğu anlaşılmıştır. ${ }^{23}$ Rivayet metinlerine göre değerlendirme yapıldığında, rivayetlerin tekrarının artmasında dikkat çeken özelliklerin ilki, sahabe döneminde tartışmalı olan, hakkında farklı görüşler bulunan konuları içermeleridir. İkinci özellik ise rivayetin konusunun, toplum tarafından yadırganan bir davranışı doğrulaması, genel kanaat veya uygulamadan farklı bilgi içermesidir. Bir diğer özellik, rivayette öğrenilmek istenen dinî bir meseleye dair bilgi bulunmasıdır. Anlaşılan sahabe döneminde toplumda ilgi ve ihtiyaç duyulan konulara dair rivayetler araştırılmış, böylelikle ilgili rivayetlerin tekrarı artmıştır. ${ }^{24}$

Hz. Muhammed'in (s) eşleri içinde ilmiyle en meşhur olanı Âişe bnt. Ebî Bekir'dir (s). Evlilik yaşının genç, evlilik tarihinin erken, vefat tarihinin ise geç olması ona ilmini arttırmakta da yaymakta da avantaj sağlamıştır. Ayrıca râvileri arasında akrabalarından, özel-

23 Kotan, Kadın Sahabîlerin Rivayetlerinin Değerlendirilmesi, 273-274.

24 Kotan, Kadın Sahabîlerin Rivayetlerinin Değerlendirilmesi, 276-277, 302-403. 
likle yeğenlerinden hadis ilmiyle meşhur birçok isim bulunmaktadır. Rivayetlerinde görülen ilmi öğrenme-öğretme azmi ve keskin zekâsı sayesinde de İslâmî ilimlerde haklı şöhretine ulaşmıştır.

İslâmî ilimleri içinde zamanla en meşhur olduğu ilim dalı ise "Hadis"tir. Onun mevsû'at'ını toplayıp beş bin altı yüzün üzerindeki rivayetini konu başlıklarına göre sıralayan bir eser mevcuttur. ${ }^{25}$ Zührî'den aktarılan “Şayet, Allah Resûlü'nün bütün eşleri ve diğer bütün kadınlarının ilmi bir araya getirilse, Âişe'nin ilmi daha fazladır" 26 sözü, onun bütün rivayetleri dikkate alındığında doğru çıkmaktadır. Zira onun gerek rivayetlerinin gerek râvilerinin sayısı gerekse rivayetlerinin konu çeşitliliği kalan kadın sahabîlerin toplamınınkilerden fazladır. Rivayet sayısında tekrarlıda 2 bin 630, tekrarsızda 687, erkek râvide 150 üzeri ve kadın râvide 50'den fazla kişi, rivayet konularında envai çeşitlilik diğer kadınlardan herhangi birinin ya da hepsinin birlikte ulaşabildikleri sınırlar değildir. Hakkında sahabeden Ebû Musa (s) tarafından yapılan "Allah Resûlü'nün ashabının rivayet ettikleri herhangi bir hadiste müşkülat görürsek, Aişe'ye sorardık, mutlaka ona bir açıklama getirirdi" yorumu da bu durumu desteklemektedir. ${ }^{27} \mathrm{Bu}$ yüzden ona insanların en alimi, görüşü kuvvetlisi, sahabenin büyüklerinin danıştığ kişi denilmiştir. ${ }^{28}$ Onun sorduğu ve ona sorulan soruların çokluğu, ihtilaflı meselelerde görüşünün alınması, kadınlar konusunda aktarılan yanlış rivayetlere itirazları dikkat çekmektedir. Sahabenin rivayetlerini doğru bulmadığında eleştirmiş, ${ }^{29}$ yanlışlarını düzeltmiş, Medine dışına çıktığında da ilim meclislerini sürdürmüştür. Zira kadın râvilerinden en çok rivayeti olan ikinci isim Muâze bnt. Abdullah el-Adeviyye ondan ilmini, Hz. Âişe Basra'ya gittiğinde almiştır. ${ }^{30}$

Resulullah'ın hanımları arasında hadis rivayetinde ikinci s1rada yer alan Ümmü Seleme (s) hakkında da müstakil eser kaleme

25 Abdülmün'im Hifnî, Mevŝ́'atu ümmi'l-Mü'minîn Âişe binti Ebî Bekr (Kahire: Mektebetü Medbulî, 2003).

26 İbn Hacer, Ebü'l-Fazl Şihâbüddîn Ahmed b. Alî b. Muhammed b. Hacer el-Askalânî, Tehzîbu't-Tehzîb (Beyrut: Dâru ihyâi't-türâsi'l-Arabî, 1991), c. VI, 605.

27 Tirmizi, "Menâkıb", 62.

28 İbn Hacer, İsâbe fî temyîzi's-Sahâbe c. VIII, 231-235.

29 Bu konuda yazılan bir eser: Bedreddîn Zerkeşî, el-İcâbe, Hz. Âişe'nin Sahabeye Yönelttiği Eleştiriler, çev. Bünyamin Erul (Ankara: Kitâbiyât Yayınları, 2002).

30 Aynur Uraler, "Muâze el-Adeviyye", DIA (Ankara: TDV Yayınları 2005), c. XXX, 341. 
Ahmed b. Hanbel ve Tayâlisî Müsnedlerinde Rivayeti Bulunan Kadın Sahabîlerin... alınmış olup geniş kaynak taraması ${ }^{31}$ ile rivayetlerinin sayısı; tekrarsız 788, tekrarlı 1.248 olarak verilmiştir. ${ }^{32}$ Hazırlanan bir tezde ise Kütüb-i Sitte'de tekrarsız 242, tekrarlı 407; Kütüb-i Tis‘a’ya Beyhakî̀nin Sünen'i ve Abdürrezzâk'ın Musannef'i dahil edilince; tekrarsız 579, tekrarlı 991 rivayeti olduğu söylenilmiştir. ${ }^{33}$ Çalışmamızda ise toplam 300, tekrasızda 100 rivayeti, elliden fazla râvisi, rivayetlerinin konu çeşitliliğiyle kadın sahabîlerden rivayet sayısı sıralamasında Hz. Aişe'den sonra yer almaktadır. En son vefat eden Peygamber eşi olduğu ve Allah Resûlü ile yaklaşık yedi yıl evli kaldığı düşünülürse, rivayetlerinin sayısı çok değildir. Kızı dışında, akrabaları içinde rivayet sayısıyla dikkat çeken bir isme ulaşılmamıştır. Azatlı kölelerinin rivayetleri de nispeten önemli sayıdadır. Hz. Peygamberin eşi olmasına rağmen, yakınları arasında -kızı dışındailmini aktaracak rivayetle tanınan bir ismin çıkmaması ve kadın olmanın dezavantajları ilmî birikimini aktarmayı zorlaştırmış olmalıdır. Sonuçta Ümmü Seleme validemizin iki Müsned' de yer alan rivayet sayısının uzun yaşamı ve ilmine nispeten az olduğu söylenebilir.

Rivayetleri içinde ibadet konularında olanlar çoğunluktadır. Kadınların özel halleri, ahkâm, Hz. Peygamber'in; ettiği ve öğrettiği dualar, tavsiye ve sakındırmaları da rivayetlerinde öne çıkan konulardandır. Tefsir rivayetlerine dair bir makale vardır. ${ }^{34}$ İhtilaflı meselelerde fikrine başvurulan, eşler arası mahrem ilişki hakkında soru sorulan, yanlış fetvayı düzelten ve Hz. Ali taraftarlığıyla tanınan bir kadındır.

Siralamada üçüncü gelen isimse 53 rivayetle Peygamberimizin baldızlarından, Esmâ bnt. Ebî Bekir'dir (s). Hakkında yapılan çalışmalar vardır. ${ }^{35}$ Uzun ömrünün yanı sıra, hadis ilmiyle meşhur Urve b. Zübeyr ve Abdullah b. Zübeyr'in annesi, Fâtıma bnt. Münzir'in

31 Kütüb-i Tis'a'ya Taberânî'nin Mu'cemleri, Abdürrezzâk'ın Musannefi, Dârekutnî ve Beyhakî'nin Sünenleri, Hâkim en-Nîsâbûrî'nin Müstedrek'i ve İbn Sa'd'ın Tabakât' 1 eklenmiştir.

32 Âmine Emizyan Hasenî, Ümmü Seleme (Rabât: Vizâretü'l-evkaf ve'ş-şuûni'lİslâmiyye, 1998), c. II, 442.

33 Abdurrahman Ay, Hz. Peygamber'in Hanımı Ümmü Seleme (İstanbul: Marmara Üniversitesi, 2003), 92.

34 Serpil Başar, “Ümmü Seleme' nin Tefsir Rivayetlerinin Değerlendirilmesi”, Dokuz Eylül Üniversitesi İlahiyat Fakültesi Dergisi 2/36 (Aralık, 2012): 428.

35 Mürvet Nur Topgül, Esmâ bnt. Ebi Bekir ve Hadis Ilmindeki Yeri, (Çanakkale: Çanakkale Onsekiz Mart Üniversitesi, 2011); Îmân Muhammed İsmâil, Merviyâtu men tüsemmeyne bi Esmâ' mine's-Sahâbiyyât, (Suudi Arabistan: Câmi'atu el-Meliki Su' ûd, 2004). 
ninesi olması, rivayet sayısının artmasını sağlamıştır. Rivayetlerinin konuları çeşitlidir. Hac konusunda naklettiği rivayetler fazladır ve tekrarları çoktur. Bunlar; hac çeşitlerinden ifrad mı temettu' mu efdaldir, ${ }^{36}$ güneş doğmadan Müzdelife'den hareket edip hava aydınlanmadan şeytan taşlamak caiz midir ${ }^{37}$ gibi hakkında ihtilaf bulunan konulardadır. Takıda zekâtın gerekli olup olmadığı ihtilafında onun uygulaması, gerekli olmadığg yönündedir. ${ }^{38}$ İhtilaflarda görüşü delil kabul edilmiş, araştırılmıştır. O da yanlış gördüğü fetvayı, dayandırılan kişiye bizzat sordurarak araştırmıştır. ${ }^{39}$ Fıkhi görüşlerini içeren rivayetlerin çokluğu ve içeriği, döneminde ilmine değer verildiğini ve kendisine fetva sorulan bir kişi olduğunu göstermektedir. Hem Mekke hem Medine döneminde yaşanan bazı olayları, ayrıntılı anlatımı dikkate değerdir ve dönemin sosyal hayatından kesitler sunmaktadır. ${ }^{40}$

Kadın sahabîler arasında dördüncü, Hz. Peygamber'in eşleri içinde ise üçüncü sırada 45 rivayetle, Meymûne bnt. Hâris (s) bulunmaktadır. Halbuki M. Yaşar Kandemir, Hz. Peygamber'in eşlerinin rivayet sayılarına dair yaptığı sıralamada, ${ }^{41}$ Ümmü Habîbe (s) üçüncü, Meymûne bnt. Hâris ise beşinci sırada zikredilmiştir. ${ }^{42}$ Hıfnî ${ }^{43}$ ve Asma'nın ${ }^{44}$ yaptığı listelerde ise üçüncü sırada yer almaktadir.

Rivayetlerinin sayısı hakkındaki yanılgı, rivayet sayısı daha az olan kadın sahabîler hakkında Türkçede bitirilmiş tez ve makaleler

36 Ahmed b. Hanbel, Müsned, VI, 350 (26961), 351 (25965), Müslim, "Hac", 29, İbn Mâce, "Menâsık", 41.

37 Ahmed b. Hanbel, Müsned, VI, 347 (26941) 351 (26966), Tayâlisî, Müsned, III, 212 (1747), Buhârî, "Hac", 98; Müslim, "Hac", 49.

38 İbn Ebî Şeybe, Ebû Bekr Abdullah b. Muhammed b. İbrâhim, el-Musannef, thk. Muhammed Avvâme (Cidde: Dâru'l-kıble, 2006), VI, 472, (10276).

39 Müslim, "Libâs", 2.

40 Ahmed b. Hanbel, Müsned, VI, 347, (26937, 26938), 350, (26957).

41 Siralaması şöyledir: 1- Âişe 2.210; 2- Ümmü Seleme 378; 3- Ümmü Habîbe 65; 4Hafsa 60; 5- Meymûne 46; 6- Zeyneb bnt. Cahş 11; 7- Safiyye 10; 8- Cüveyriye 7; 9- Sevde bnt. Zem'a 5 rivayet.

42 M. Yaşar Kandemir, "Hanımların Dilinden Hz. Peygamber”, Tartışmalı İlmî Toplantılar Dizisi Hz. Peygamber ve Aile Hayatı, ed. Ali Özek vd. (İlmi Neşriyat; İstanbul, ts.), 90-94.

43 Hifnî, Mevsû'atu ümmi'l-Mü'minîn Âişe, 15.

44 Sayeed, Women and the Transmission, 39. 
Ahmed b. Hanbel ve Tayâlisî Müsnedlerinde Rivayeti Bulunan Kadın Sahabîlerin... mevcutken, Meymûne validemize dair benzeri bir çalışmanın yapılmamasında ${ }^{45}$ etkili olmalıdır. Oysa onun da rivayetlerinin sayısı ve içerik çeşitliliği, müstakil bir çalışmaya kaynaklık edebilecek zenginliktedir. İbadetler, hayız, gusül, dua ve tavsiyeler rivayetlerinin konularındandır. Hz. Peygamber'in, kadınlara tavsiyede bulunduğu, ilk Müslümanlardan oldukları için kız kardeşleriyle birlikte onu övdüğ̈̈, ${ }^{46}$ onun Kur'an bilgisine itibar ettiği, ${ }^{47}$ kıskançlı̆̆ına hoşgörüyle yaklaştığ ${ }^{48}$ rivayetlerinden anlaşılmaktadır. Bulunan yiyecek bozulabilecek nitelikteyse, bozulmasındansa kullanilmasına dair görüşü ${ }^{49}$ fetva vermesine örnektir.

Siralamada beşinci isim, 40 rivayetle Hz. Peygamber'in amcakızlarından Ümmü Hânî'dir (s). Hicrî 40'lı yıllardaki vefatı, nispeten erken bir dönemdir. Râvileri arasında rivayeti tek olmayan iki isimden birisi, zayıf görülen kölesi Ebû Sâlih'tir. ${ }^{50}$ Temel iki kaynağımız dişındaki kaynaklarda tespit edilen 28 rivayetin çoğu da bu kölesindendir. Torunları râvileri arasında olsa da rivayetleri tektir. ${ }^{51} \mathrm{Bu}$ durumda, Ümmü Hânî'nin aile ilişkileri, rivayetlerinin aktarımında k1sıtlı rol oynamıştır denilebilir. Rivayetlerinde tekrar oranı, dörtte üçe yakındır. Hz. Peygamber'in Mekke'nin fethi günü sekiz rek'at duhâ kıldığına dair rivayetin bir tek Ümmü Hânî'den gelmesi, ${ }^{52}$ ilgili rivayetlerin araştırılmasına, tekrarlarının artmasına ${ }^{53}$ sebep olmuştur. Fıkhi görüşleri de rivayet edilmiştir. ${ }^{54}$ Rivayetlerine göre Hz. Peygamber, akrabası olan Ümmü Hânî'yi ziyarete gidip yemek

Çalışma tamamlandıktan sonra Dr. Ali Karakaş'ın hazırladığı "Hazreti Meymûne ve Sahihayn Rivayetleri" isimli bir eser yayınlandı.

Taberânî, Mu'cem, XXIV, 19.

Taberânî, Mu'cem, XXIV, 29.

48 Hâkim en-Nîsâbûrî, Ebû Abdullah İbnü'l-Beyyi Muhammed, el-Müstedrek ale'sSahîhayn, thk. Şemsüddîn Ebî Abdullah (Haydarâbâd: Dâru'l-kütübi'l-ilmiyye, 1915) "Ma'rifetü's-Sahâbe", III, 30.

49 İbn Ebî Şeybe, Musannef, XI, 225 (22073).

50 Ebû Sâlih. (Ahmed b. Hanbel, Müsned, VI, 341 (26891), 342 (26898), 344 (26911), 424 (27383), Tayâlîsî, Müsned, III, 187 (1720), 190 (1724)

51 Yahyâ b. Ca'de (Ahmed b. Hanbel, Müsned, VI, 341-342). Meçhul denilenler: Ca'de (Ahmed b. Hanbel, Müsned, VI, 341 (26893) ), Hârûn (Ahmed b. Hanbel, Müsned, VI, 343-344 (26910))

52 Mehmet Şener, "Kuşluk Namazı", DİA (Ankara: TDV Yayınları, 2002), c. XXVI, 475 .

53 Ahmed b. Hanbel, Müsned, VI, 341 (26892, 26888, 26889), 342 (26900, 26901, 26896, 26898, 26899), 343 (26903, 26904, 26906-26908), 423 (27379-27380), 425 (27388, 26391, 27392), Tayâlisî, Müsned, III, 187 (1720), 191 (1725) ve diğerleri.

54 İbn Ebî Şeybe, Musannef, I, 461 (709). 
talep etmiş, ${ }^{55}$ ona tavsiyelerde bulunmuş, ${ }^{56}$ onun sorularını cevaplamış ${ }^{57}$ ve verdiği emanı geçerli saymıştır. ${ }^{58}$

Altıncı sırada Ensardan bir isim, 30 rivayetle Esmâ bnt. Yezîd (s) yer almaktadır. Hakkında tez hazırlanmıştır. ${ }^{59}$ H. 15 senesinden sonra Dımaşk'a yerleşip vefatına kadar burada kalan Esma, Şam bölgesine hadis ve fıkıh taşıyan sahabenin ilklerindendir. ${ }^{60}$ Râvileri listesinde bir yeğen, ${ }^{61}$ iki köle ismi geçmektedir ${ }^{62}$ ve içlerinde öne çıkan isim, zayıf görülen kölesi Şehr b. Havşeb'dir. ${ }^{63} \mathrm{~Hz}$. Peygamber' in tavsiyelerini anlatmaya özel gayret ettiği, ${ }^{64} \mathrm{Kur}^{\prime}$ an, ${ }^{65}$ kıraat $^{66}$ ve ahkâma ${ }^{67}$ dair bilgili olduğu anlaşılmaktadır.

Esma'dan sonra sırasıyla Peygamberimizin iki eşi, Ümmü Habîbe (s) ve Hafsa bnt. Ömer (s) gelmektedir. İkisi hakkında da müstakil çalışmalar vardır. ${ }^{6}$ Ümmü Habîbe'nin rivayet sayısı

55 Tirmizî, "Et'ime", 35.

56 Ahmed b. Hanbel, Müsned, VI, 342-343 (26902) 424 (27381), İbn Mâce, "Ticârât", 69; İbn Mâce, "Edeb", 54.

57 Ahmed b. Hanbel, Müsned, VI, 341 (26891), Tayâlisî, Müsned, III, 189 (1422), Tirmizî, "Tefsîr", 30; Ahmed b. Hanbel, Müsned, VI, 344 (26911), 425 (27393), İbn Mâce, "Edeb", 56; Ahmed b. Hanbel, Müsned, VI, 424-425 (27387).

58 Müslim, "Hayz", 16; Ebû Davûd, "Tetavvu' ", 12.

59 Kadir Öztürk, Esmâ Bnt. Yezîd'in Hayatı ve Rivayetleri (İstanbul: Marmara Üniversitesi, 2010).

60 Ağırakça Şahyar, Ayşe Esra, Seyahat ve Rivayetleriyle Hanım Sahabîler (İstanbul: Akdem Yayınları, 2015), 62-65.

61 Mizzî, Kemâl, XXXV, 128; Öztürk, Esmâ Bnt. Yezîd'in Hayatı ve Rivayetleri, 20. Mahmûd b. Amr, erkek kardeşi Amr b. Yezîd'in oğlu.

62 Öztürk, Esmâ Bnt. Yezîd'in Hayatı ve Rivayetleri, 34-41; Mizzî, Kemâl, XXXV, 128. Bahsi gelecek olan Şehr b. Havşeb ve iki Müsned'de tek rivayeti olan Muhammed b. Ebî Müslim bk. Ahmed b. Hanbel, Müsned. VI, 453, (27562), 457 (27585).

63 İbn Hacer, Ebü'l-Fazl Şihâbüddîn Ahmed b. Alî b. Muhammed b. Hacer el-Askalânî, Lisânü'l-mîzân, thk. Muhammed Abdurrahman Maraşli (Beyrut: Dâru ihyâi't-türâsi'l-Arabî, 1995), VIII, 392.

64 Ahmed b. Hanbel, Müsned, VI, 454 (27570), 459 (27597; 27599, 27601), Tirmizî, "Bir", 26; İbn Mâce, "Zühd", 4 ve diğerleri.

65 Ahmed b. Hanbel, Müsned, VI, 460 (27607) , 461 (27611); Ebû Davûd, "Vitr", 23; Tirmizî, "Deavât", 66.

66 Ahmed b. Hanbel, Müsned, VI, 454 (27569), 459 (27595, 27596), Tayâlisî, Müsned, III, 200, (1736).

67 Ahmed b. Hanbel, Müsned, VI, 455 (27576), Ebû Dâvûd, "Talâk", 36.

68 Süleyman Gümrükçüoğlu, Hz. Hafsa'nın Hayatı ve Rivayetleri (İstanbul: Marmara Üniversitesi, 2004); Fatma Ateş, Hz. Peygamber'in Hanımlarından Hafsa'nın Hayatı, Kişiliği ve İslâm Tarihi'ndeki Yeri (Urfa: Harran Üniversitesi 2007); Emine Peköz, Hz. Peygamber'in Hanmmlarnndan Ümmü Habîbe'nin Hayatı, Kişiliği ve İslâm Tarihi'ndeki Yeri (Urfa: Harran Üniversitesi, 2012); Aynur Uraler, Peygamberimizin Hanımı Ümmü Habîbe ve Rivayet Ettiği Hadisler (İstanbul: Çamlıca Yayınları, 2010). 
Ahmed b. Hanbel ve Tayâlisî Müsnedlerinde Rivayeti Bulunan Kadın Sahabîlerin... 26'dır. İbadetler, müjde ve uyarılar, eşler arası mahrem hayat ve Hz. Peygamber'e sorulan fetvalar rivayetlerinde geçmektedir. Ateşte pişen yiyeceklerden abdest gerekir mi ${ }^{69}$ ve oruçluyken eşini öpme ${ }^{70}$ gibi döneminin ihtilaflı meselelerine dair de rivayetleri vardır. Onun da sahip olduğu ilim ve birikimin az bir kısmının günümüze ulaştığını söyleyebiliriz. Hafsa bnt. Ömer'in ise rivayet sayısı 25'tir. Rivayetleri başta ibadet olmak üzere; ahkâm, gayb ve tavsiye konularını içermektedir. H. 40'lı yıllarda vefatına, sekiz yıllık evliliğine ve muksirûndan Abdullah b. Ömer'in k1z kardeşi olmasına rağmen, ulaşılan rivayeti az sayıdadır.

Rivayeti onun üzerine çıkan Hz. Peygamber'in hısımlarından diğer iki isimin, genel sıralamada dokuzuncu sıradaki baldızı Esmâ bnt. Umeys'in (s) 23, on dördüncü sıradaki yengesi ve baldızı Ümmü Fazl (s)'ın 16 rivayetine ulaşılmıştır. Esmâ bnt. Umeys'in vefat tarihi için verilen 40'l1 yıllar da erken dönem sayılır. Onun râvileri arasında oğlunun, ${ }^{71}$ iki torununun ${ }^{72}$ ve üvey kızının ${ }^{73}$ isimleri geçse de rivayet sayıları azdır. Rivayetleri içinde tıbb-1 nebevî $\hat{1}^{74}$ ve Hz. Ali'nin (s) faziletine dair olanlar ${ }^{75}$ çoğunluktadır. Hz. Ali'nin eşi olan Esma'nın kocası ile ilgili güvenilir olmayan rivayetlerin bir kısmına kaynak gösterilmesi şaşırtıcı değildir. ${ }^{76}$ Resûlullah'ın ilgi ve tavsiyelerine mazhar olduğu,77 sorduğu soruların cevaplandığı; siyasi olaylar, Habeşistan'da görüp duydukları, ahkâma dair rivayetlerde bulunduğu görülmektedir. Ümmü Fazl'ın ise hicrî 30'lardaki erken vefatına rağmen oğlu Abdullah b. Abbâs ve sahabeden Ab-

Ahmed b. Hanbel, Müsned, VI, 326, 327, 426, 427; Tayâlisî, Müsned, III, 168-169.

Ahmed b. Hanbel, Müsned, VI, 325 (26762).

Abdullah b. Ca'fer bk. Ahmed b. Hanbel, Müsned, VI, 369, (27082).

72 Kâsım b. Muhammed bk. Ahmed b. Hanbel, Müsned, VI, 369, (27084). Semâ1 yok denilmektedir. Ümmü Ca'fer bnt. Muhammed bk. Ahmed b. Hanbel, Müsned, VI, 370, (27086).

73 Fâtıma bnt. Ali b. Ebî Tâlib bk. Ahmed b. Hanbel, Müsned, VI, 369, (27081); 438, (27467).

74 Ahmed b. Hanbel, Müsned, VI, 369 (27080), 438 (27470); Tirmizî, "Tıb", 17, 30; İbn Mâce, "Tib", 1, 33.

75 Ahmed b. Hanbel, Müsned, VI, 369 (27081), 438 (27467).

76 Taberânî, Mu'cem, XXIV, 144-145; Ahmed b. Hanbel, Ebû Abdullah Ahmed b. Muhammed b. Hanbel eş-Şeybânî, Kitâbü Fezâilü's-Sahâbe (Mekke, Camiatü Ümmü'l-Kurâ, 1983) II, 675 (1158)

77 Ahmed b. Hanbel, Müsned, VI, 369 (27083), 438 (27468); 370 (27086), İbn Mâce, Cenâiz, 59. 
dullah b. Hâris b. Nevfel'in râvileri arasında bulunması, rivayetlerinin aktarılmasını sağlamış olmalıdır. Anlattıkları Allah Resûlü'nün akrabalarıyla yakın ilişkisine 1 şı tutmaktadır. ${ }^{78}$

Hz. Fâtıma'nın (s), babasının vefatının ardından bir yıl geçmeden vefat etmesi rivayetlerini azaltsa da kadın sahabe arasında rivayet sayısı sıralamasında 23 rivayetle onuncu sıradadır. Torunları ve sahabe vasıtasıyla rivayetleri kaynaklarda yer alabilmiştir. Rivayetleri içinde, zayıf ve mevzû ${ }^{79}$ olanlar vardır. Erken vefat tarihine rağmen onun söylediklerine verilen değer, duyulan özlem; bu rivayetlerin aşırı zaaflarına rağmen bazı kaynaklara girmesinde rol oynamış olabilir. Hz. Ali'in eşi olmasıyla da onun faziletine dair mevzû denilecek kadar zayıf olan rivayetlere kaynak gösterilmiştir. ${ }^{80}$

Ensardan iki isim, genel sıralamada on bir ve on ikinci sırada yer alan, Ümmü Atıyye'nin (s) 19, Ümmü Süleym'in (s) 18 rivayetine ulaşılmıştır. Ümmü Atıyye'nin rivayetleri içinde fıkıh bilgisine ve fetvalarına dair olanlar çoğunluktadır. Onun, "Mâûn" kelimesinin anlamına dair rivayeti ise Kur'an lafızları hakkında bilgisini göstermektedir. Bir makalede, bu kelimenin manasına dair rivayetlerde verilen 20 anlam sayılmaktadır. ${ }^{81}$ Balta, terazi, kova, tencere, su, taş, demir, ev eşyaları, ödünç verilen eşyalar, iğne, kova, kalbur, elek gibi eşyalar; zekât, hayır, mal, iyilik, taat, ödünç, iyilik ve hayra ait her şey geçen manalardır. Ümmü Atıyye'den gelen rivayette verilen mana "İnsanların muhtaç oldukları eşyalar", 82 tüm diğger manaları kapsamaktadır. O, ölü yıkanmasında yetkindir ${ }^{83}$ ve Basra'ya yerle-

78 Ahmed b. Hanbel, Müsned, VI, 339-340 (26874, 26875, 26876, 26878, 26882) ; Ebû Davûd, "Tahâra", 136; İ̉n Mâce, "Ta'bîr", 10; Taberânî, Mu'cemü'l-Evsât, X, 115 (9246).

79 Taberânî, el-Mu'cemü'l-Evsat, I, 105 (103), İbnü'l-Cevzî, Ebü'l-Ferec Cemâlüddîn Abdurrahmân b. Alî b. Muhammed Bağdâdî, Kitâbü'l-Mevzûât, thk. Abdurrahman Muhammed Osman (Beyrut: Dâru'l-Fikr, 2. Baskı, 1983), III, 57.

80 Ahmed b. Hanbel, Kitâbü Fezâili's-Sahâbe, II, 658, (1121). Rivayetin dipnotunda, mevzû denilmektedir. Ebû Ya'lâ el-Mevsılî, Ahmed b. Ali b. Müsennâ, Müsnedu Ebî Ya'lâ el-Mevssllî, thk. Mustafa Abdülkadir Atâ (Beyrut, Dâru'l-Kütübi'l-İlmiyye, 1998) XII, 117 (6749).

81 Mustafa Karataş, "Hadis Sayım Metodlarının Hadislerin Sayısına Etkisi”, ILAM Araştırma Dergisi 3/2 (Temmuz-Aralık 1998), 66.

82 Taberânî, Mu'cem, XXV, 67.

83 Hz. Peygamber' in kızları Zeyneb ve Ümmü Külsûm'ün cenaze hizmetlerinde de görev almıştı. İki rivayeti bu konudadır: Ahmed b. Hanbel, Müsned, V, 84 (20791), 85 (20795, 20800-20801), VI, 407 (27297), 408 (27302), Buhârî, "Vudû' ", 31, "Cenâiz",8; Müslim, "Cenâiz", 12. 
Ahmed b. Hanbel ve Tayâlisî Müsned'lerinde Rivayeti Bulunan Kadın Sahabîlerin... şip buranın bir ilim merkezi hâline gelmesinde etkili olan ashaptandır. ${ }^{84}$ Savaşlara katılarak geri hizmet sağlamış ve hemşirelik vazifesi yapmıştır. ${ }^{85}$ Medine' de ilk Müslümanlardan olan Ümmü Süleym ise Allah Resûlü'nün yakın ilgisine ve ziyaretine mazhar olmuş, ${ }^{86}$ hamile olduğu hâlde Huneyn, öncesinde Uhud Gazvesi'ne katılmıştır. ${ }^{87}$ İstediği soruları Resûlullah'a soracak yakınlığa, 88 ihtilaflı meselede geçerli şahitliğe ${ }^{89}$ ve farklı konularda fıkhi bilgiye ${ }^{90}$ sahiptir. Hz. Ömer'in hilafeti dönemindeki erken sayllacak vefat tarihine rağmen ${ }^{11} \mathrm{~Hz}$. Peygamber'in hizmetine vererek eğitimini sağladığı oğlu, muksirûndan Enes b. Mâlik'in de katkısıyla, rivayetleri kaynaklarımiza geçmiştir. Muhacirden olup 10 rivayeti bulunan Şifâ bnt. Abdullah ise Hz. Ömer'in amcasının kızıdır. Hicret öncesi biat etmiştir. Râvisi olarak bir oğlu, iki torunu, bir kölesi ve Hafsa bnt. Ömer'i sayılmıştır. ${ }^{92}$ Rivayetlerinde fikıh, ${ }^{93}$ yazma öğrettiği, ${ }^{94}$ rukye yaptığ ${ }^{9},{ }^{95}$ en faziletli amel ${ }^{96}$ ve Hz. Peygamber'i ziyaret ettiği ${ }^{97}$ gibi konular geçmektedir.

Hz. Peygamber'in azadlılarından, genel sıralamada on üçüncü Meymûne bnt. Sa'd'ın (s) 17, on beşinci Ümmü Eymen'in (s) 11 ve

\footnotetext{
84 Ağırakça Şahyar, Seyahat ve Rivayetleriyle Hanım Sahabîler, 127

85 Ahmed b. Hanbel, Müsned, V, 84 (20792), VI, 407 (27300), Müslim, "Cihâd", 50; İbn Mâce, "Cihâd", 37. Ebe-hemşire oluşuyla rivayetlerinin bağlantısına bir makalede değinilmektedir. Seyit Ali Güşen, "Sahabe Mesleklerinin Hadis Rivayetlerine Etkisi", Dinbilimleri Akademik Araştırma Dergisi 19/2 (2019), 351-353.

86 Ahmed b. Hanbel, Müsned, VI, 376 (27115), 431, (27428, 27430), Tayâlisî, Müsned, III, 222 (1755).

87 İbn Sa'd, Ebû Abdullah Muhammed b. Sa'd b. Meni' ez-Zührî, et-Tabakâtu'lKübrâ, (Beyrut: Dâru Sadır, 1968), VIII, 312-314, Taberânî, Mu'cem, XXV, 123-124. Ahmed b. Hanbel, Müsned, VI, 376, r. 27114; 377, r. 27118; Müslim, "Hayz", 7.

89 Ahmed b. Hanbel, Müsned, VI, 431 (27431-27432), 430-431 (27427), Tayâlisî, Müsned, III, 224 (1756); Buhârî, "Hac", 145.

90 Müslim, "Hayz", 7; Taberânî, Mu'cem, XXV, 129,123-124, 127; Taberânî, Mu'cemü'l-Evsat, V, 12 (4212).

91 M. Yaşar Kandemir, “Ümmü Süleym”, DİA (Ankara: TDV Yayınları, 2012) c. XLII, 330-331.

92 Mizzî, Kemâl, XXXV, 207.

93 Taberânî, $M u^{\prime} c e m$, XXIV, 313

94 Ahmed b. Hanbel, Müsned, VI, 372 (27095), Ebû Davûd, "Trb", 18.

95 Hâkim en-Nîsâbûrî, Müstedrek, "Ma'rifetü's-Sahâbe", IV, 57

96 Ahmed b. Hanbel, Müsned, VI, 372 (27094, 27096).

97 Taberânî, Mu'cem, XXIV, 314.
} 
on altınc1 ${ }^{98}$ Selmâ Ümmü Râfi' 'in (s) 10 rivayetine ulaş1lmıştır. Böylelikle rivayet sayısı ona ulaşanlar arasında yer almışlardır. Meymûne bnt. Sa'd'ın rivayetlerinin 14'ü farklı kaynaklardandır ve sened yönünden hemen hepsi eleştirilip zaafına işaret edilmiştir. Bu rivayetlerin naklettiği hadislerin konuları ise ya kadınlara dairdir ya da fetva sorması sonucu aldığ 1 cevaplardır. ${ }^{99} \mathrm{~Hz}$. Peygamber'in ailesi içinde sayılabilecek Ümmü Eymen'in ise ondan duyduğu hüküm ve tavsiyelerin ${ }^{100}$ birkaçını anlattığı, görüşlerinin isabetli ve hikmetli olduğu ${ }^{101}$ anlaşılmaktadır. Selmâ Ümmü Râfi' 'nin ise rivayetleri çoğunlukla tıbb-1 nebevîye, ${ }^{102}$ günlük yeme-içme alışkanlı$\breve{g} 1 n{ }^{103}$ ve Hz. Peygamber'in tavsiyelerine ${ }^{104}$ dairdir. Konular onun ebe-hemşire oluşuyla da bağlantılıdır.

Hz. Peygamberin eşlerinden, vefat tarihleri için hicrî 20’ler zikredilen Zeyneb bnt. Cahş'tan (s) 10, Sevde bnt. Zem'a'dan (s) 9 rivayetin bulunması, erken vefat tarihleriyle bağlantılıdır. Safiyye bnt. Huyey'in (s) 10 ve Cüveyriye bnt. Hâris'in (s) 9 rivayeti varken ikisinin de râvileri arasında akraba isimleri yoktur. Oysaki vefat tarihleri, hicrî 50'ler gibi nispeten geç bir dönemdedir. Eş olma ve geç vefat tarihi avantajlarına rağmen, aile ilişkileri açısından dezavantaj olan Yahudi kökenli olmaları, rivayetlerini sınırlandırmış olmalıdır.

Allah Resûlü'nün akraba ve hısımlarından, Dubâ'a bnt. Zübeyr'in (s) ve Havle bnt. Kays'ın (s) 5, künyesi Ümmü Münzir olan Selmâ bnt. Kays'ın (s) 3, Ümmü Hakîm'in (s) 2 rivayetine ulaşılmıştır. Kalan isimlerin sadece bir rivayeti bulunmaktadır. Hatta bu

98 Kadın sahabe arasında rivayet sayılarına göre yaptığımız sıralamada on rivayetine ulaşılan dört kadından biridir. Diğerleri, Hz. Peygamber'in eşlerinden Zeyneb bnt. Cahş ve Safiyye bnt. Huyey ile muhacirden Şifâ bnt. Abdullah'tır.

99 Taberânî, $M u^{\prime}$ cem, XXV, 35-39.

100 Ahmed b. Hanbel, Müsned, VI, 421, r. 27364, Taberânî, Mu'cem, XXV, 87-88, 91, 89.

101 İbn Ebî Şeybe, Musannef, "Cenazeler", XVI, 7, 193 (11277), 280, Taberânî, Mu'cem, XXV, 86, 88, 89-90.

102 Ahmed b. Hanbel, Müsned, VI, 462 (27617), Ebû Davûd, "Tıb", 3, İbn Mâce, "Tıb", 29.

103 Taberânî, $M u^{\prime} c e m$, XXIV, 298, 300.

104 İbn Mâce, "Et'ime", 38,Taberânî, Mu'cem, XXIV, 299. 
Ahmed b. Hanbel ve Tayâlisî Müsnedlerinde Rivayeti Bulunan Kadın Sahabîlerin...

isimlerden ikisi, muhtemelen tekrardır. ${ }^{105}$ Bazıları hakkında herhangi bir bilgiye ulaşılamamıştır. ${ }^{106}$ Farklı şahısların rivayetlerindeki tekrarlar göz ardı edilirse, onlardan gelen toplam rivayet sayısı, 75 'tir. Allah Resûlü'ne akraba olan kadınlar hakkında bilgilerin ve onların rivayetlerinin sınırlı ölçüde korunabildiği, bazılarının isimkünye bilgisi gibi temel bilgilerinin dahi ayırt edilemediği, anlaşılmaktadir.

Tek rivayetine ulaşılan kadın sahabîlerin her birinden bahsetmek makale sınırlarını aşacaktır. Özetle, onların rivayetlerinin aile içinde aktarılmasının ve râvilerinin meçhul görülmesinin daha da yaygın olduğunu söyleyebiliriz. İçlerinde Hz. Peygamber'e bir ihtiyaç veya soru sormak için gelenler, ondan duyduğu bir tavsiye veya sakındırmayı ya da Veda Haccına katıldıkları sırada şahit olduklarını aktaranlar çoğunluktadır.

Buraya kadar çoğu kadın sahabîlerin rivayetlerinin sayısal mevcudiyeti hakkında yapılan değerlendirmeler, bu mevcudiyetin sınırlı olduğunu göstermektedir. Hz. Âişe'den aktarılanların bile mümkün, makul hatta beklenebilecekten az olduğu söylenebilir. Rivayet sayısı artan bir kadın sahabînin, üç genel özelliğe mutlaka sahip olduğu saptanmıştır. Temel hadis kaynaklarında kadın sahabîlerin rivayetlerinin azlığı, çoğunluğunun bu özelliklere bir arada sahip olamamasıyla açıklanabilir.

\section{Kadın Sahabîlerin Rivayet Sayısının Artma-Azalma Sebepleri}

Kadın sahabîlerin rivayet sayıları değerlendirilirken rivayet sayısının artıp-eksilmesinde etkili olan sebepler, tekrarlanan örneklerle dikkat çekmiştir. Öyle ki üç özelliğe bir arada sahip olmayan kadınların rivayet sayısı da beşin üstüne çıkamamıştır.

Bu özelliklerin ilki vefat tarihinin geç olmasıdır. Sahabe râvisinin vefat tarihinin geç ya da erken oluşunun rivayet sayısının artışı ya da azalışı üstünde direk etkisi bilinmektedir. Çünkü Hz. Peygamber'in vefatını takip eden sahabe döneminin başlarında, riva-

\footnotetext{
105 Hamne bnt. Cahş ile Ümmü Habîbe bnt. Cahş'ın, Dubâ'a bnt. Zübeyr ile Ümmü Hâkim bnt. Zübeyr'in aynı kişi olabilir bk. Kotan, Kadın Sahabîlerin Rivayetlerinin Değerlendirilmesi, 143-150.

106 Selmâ bnt. Hamza bk. Kotan, Kadın Sahabîlerin Rivayetlerinin Değerlendirilmesi, 151-152.
} 
yetler çoğunlukla şifâhen, doğal bir seyir içinde araştırılıp öğrenilmektedir. ${ }^{107}$ Sahabe sayısı fazla olduğundan, bilgilerin kaybolacağ 1 gibi bir endişe baş göstermemiştir. Allah Resûlü'nün en yakınlarından bile, sahip oldukları ilme ulaşmak gayretiyle, sorular sorulup cevapları kaydedilmemiştir. Mesela vefatı kendisinden sonraya kalan biricik evladı Hz. Fâtıma'dan, 24 rivayet tespit edebilmemiz, erken vefatıyla açıklanabilir ki bu ona özel bir durumdur. Hz. Peygamber'in vefatının üzerinden 10 yıl geçmeden vefat edip 10 üzerinde rivayeti olan başka kadın sahabî yoktur. Benzer şekilde, Hz. Peygamberin eşlerinden, Zeyneb bnt. Cahş'ın ve Sevde bnt. Zem'a'ın az sayıda rivayetinin bulunması da erken vefat tarihleriyle bağlantılı olmalıdır.

Vefat tarihinden sonra dikkat çeken ikinci özellik, Hz. Peygamber'e yakınlıktır. Bu yakınlık eş veya akrabalık bağıyla olabileceği gibi İslam'da öne geçip sahabenin ileri gelenleri arasında bulunmakla da olabilir. On ve üzeri sayıda rivayeti bulunan kadın sahabîlerden, Hz. Peygamber'in eş, akraba, hısım ve azadlıları arasından olmayan dört kişi; Esmâ bnt. Yezîd, Ümmü Atıyye, Ümmü Süleym ve Şifâ bnt. Abdullah'tır. Haklarında verilen bilgilerden ve rivayetlerinden, dördünün de sahabenin İslam'a girişte ilklerinden, ensar ve muhacirin önde gelenlerinden oldukları anlaşılmaktadır.

Hadis rivayetinde aile ilişkilerinin etkisine dair bir doktora çalışması yapılmıştır. ${ }^{108}$ Konu "Kadın Sahabîlerin Rivayetleri" olduğunda, artık bir etkiden değil, doğrudan ilişkiden bahsetmek daha isabetlidir. Rivayet sayısı iki ve üzeri olan kadın sahabenin ailelerinde, ${ }^{109}$ neredeyse mutlaka, hadis ilminde meşhur en az bir isim bulunmaktadır. Bu kadınlardan, râvileri içinde aile bireyleri öne çımayan sadece birkaç istisna isim bulunmaktadır. ${ }^{110} \mathrm{~Hz}$. Peygamberin eşlerinden rivayet sayıları az olan Safiyye bnt. Huyey'in, Cüveyriye bnt. Hâris'in ve Sevde bnt. Zem'a'nın râvileri arasında da akraba isimleri yoktur. Altı rivayetli Ümmü Kürz Kabiyye'nin (s) ve beş rivayetli Havle bnt. Hakîm (s) de râvileri arasında akraba ismine

107 Bu sürecin Râşid Halifeler döneminde doğal sürecinde aktarıldığını örnekleriyle inceleyen bir makale için bk. Halis Aydemir, "Hadis Rivayet Sisteminde Râvi Modelleri", Hadis Tetkikleri Dergisi 5/1 (2007): 85-100. Bekir Kuzudişli, Hadis Rivâyetinde Aile İsnadları (İstanbul: İşaret Yayınları, 2007). Aile kapsamına oğul, kardeş, yeğen, torun girdiği gibi köleler de girmektedir. ned'deki 10 rivayetinin sadece biri ondandır. Rubeyyi' bnt. Muavviz'in ise altı rivayetini aktaran iki erkek râvisiyle arasında akrabalık bağı anılmaz. 
Ahmed b. Hanbel ve Tayâlisî Müsned'lerinde Rivayeti Bulunan Kadın Sahabîlerin... rastlanmamıştır. Sonuçta rivayet sayıları 10'un üzerine çıkan isimlerin her birinde, râvileri içinde ailesinden tanınmış râvilerin bulunması ortak özelliktir.

Rivayet ilminde etkisi bilinen aile bağları, kadın sahabe rivayetleri konu olduğunda, belirleyicilik derecesinde etkilidir. Tek rivayeti bulunanlar da dahil olmak üzere kadınlar, çoğunlukla aile ilişkileri vesilesiyle rivayetlerini aktarmıştır. Çalışmada kadın sahabenin râvilerinde erkeklerin sayısının kadınlardan çok olduğu da görülmektedir. Kadın olmanın, sonraki dönemlerde ilmi aktarmada bir dezavantaja dönüştüğü düşünülebilir. Kadın râviler, haklarında bilgi olmadığı için, ekseriyetle meçhul konumuna düşmüşler, rivayetleri de çoğunlukla akrabalarından gelmiştir. Kadın sahabeden gelen rivayetleri azaltan etkenlerden biri de kadın râvilerinin bilinip tanınmaması, onlar yoluyla gelen rivayetlerin bir kısmının kaybedilmesi olmalıdır.

Kadın sahabîlerin rivayetleri değerlendirilirken konularını da dikkate almak gerekir. Rivayetlerin hangi konularda yoğunlaştığı, dönemin kadınlarının yaşantı, ilgi ve vasıflarına ışık tutacaktır.

\section{Kadın Sahabîlerin Rivayetlerinin Konuları}

İncelenen rivayetler konularına göre sınıflandırıldığında "İbadetler" konusunda sayıca en fazla rivayetin yer aldığı görülmektedir. Özellikle eşler ve akrabalardan gelen rivayetlerde, "İbadetler" üst başlığı , üçte bir oranında yer tutmaktadır. Eş ve akraba haricî kadınlardan gelen rivayetlerde ise bu oran azalır. İbadet konusunun alt başlıklarından tüm bölümlerde rivayet sayısı açısından ilk sırada gelen "Namaz"dır. Ardından "Hac", "Dua" ve "Oruç" alt başlıklarındaki rivayetlerin sayısı birbirine yakındır. Oluşan tablo, kadınların dinin temel konularında bilgili olduklarını göstermektedir. "Ahkam"a dair rivayet sayılarının yüksek oluşu da bu göstergeyi doğrular.

“Temizlik" üst başlıklarındaki rivayetler, kadınların özel durumlarına ait hayız ve nifas konularında yoğunlaşmaktadır. Bu konuların kadınlar tarafından öğrenilmesi ve aktarılması doğaldır. $\mathrm{Bu}$ başlıklardaki rivayetlerin dikkate değer çoğunluğu, kadınların Hz. Peygamber'e gelip soru sormaları neticesinde edindikleri bilgileri 
ihtiva eder. ${ }^{111}$ Toplumda yaygın kanaatin aksine hayılı kadının temiz olduğu, özellikle eşlerden gelen rivayetlerde, Allah Resûlü'nün tutum ve davranışlarıyla vurgulanır. ${ }^{112}$

"Emir-Yasak-Tavsiye" çok sayıda rivayet bulunan başlıklardandır. Eş ve hısım-akraba haricî kadınların rivayetlerinde ise en çok rivayetin bulunduğu başlıktır. Allah Resûlü'nün tebliğci-eğitimci vazifesini, kadınlar için de özenle yerine getirdiği; özellikle bir vesileyle karşılaştıklarına hayatlarında iz bırakacak, gelecek nesillere aktaracakları nasihatlerde bulunduğu; onların da edindikleri kazanımları imkânları çerçevesinde paylaştıkları anlaşılmaktadır.

"Gayb" başlığı da dikkate değer sayıda rivayeti barındırır. İçerdikleri rivayetlerin bir kısmının uzun metinlere sahip, kıssa tarzı, olağanüstü olaylarla süslü, gelecekten -özellikle Müslümanların başına gelecekler-, siyasi çekişmeler, fitneler, Deccal, Mesih vb.- haber veren rivayetler olması, ihtiyatla yaklaşmayı düşündürebilir. İnsanların her dönemde var olan bilinmeyene karşı merakı ve ilgisi bu rivayetlerin aktarılmasını kolaylaştırmış olmalıdır.

"Nikâh" konusunda gelen rivayetler, kadın bekâr olsun dul olsun, rızası alınmadan kıyılan nikâhın geçerli olmadığını, ${ }^{113}$ kadının başvurusuyla boşanmanın mümkün olduğunu, ${ }^{114}$ cariye-hür her kadının eşiyle ilgili şikâyetlerini Allah Resûlü'ne iletebildiğini göstermektedir. Hz. Peygamber'in kadınların evlilik tercihleriyle ilgilendiğinin, 115 dindar kadının boşanmasını "günah" diye adlandırdı̆̆ının örnekleri ${ }^{116}$ de mevcuttur. Eşinden şiddet gördüğü ya da eşini beğenmediği için ayrılma talebinde bulunan kadının, isteğini yerine

111 Ahmed b. Hanbel, Müsned, VI, 381-382 (27144); 345-346, (26920, 26932); 439-440 (27475); İbn Mâce, "Tahâra", 117; Nesâî, "Tahâret", 126; Ebû Davûd, "Tahâra", 108; Nesâî, "Tahâra", 138 ve diğerleri.

112 Ahmed b. Hanbel, Müsned, VI, 214, 245, 45, 229, Müslim, "Hayz", 3, Ebu Davûd, "Tahâra", 104; Ahmed b. Hanbel, Müsned, VI, 72, 78, 135, 158, 330-336, 345; Buhârî, " Hayz", 3, 4, 5, 30; Müslim, "Mesâcid", 51, "Hayz", 1 ve diğgerleri.

113 Ahmed b. Hanbel, Müsned, VI, 78 (24494); 328 (26786, 26787-26789); 373 (27100), 411 (27320), Tayâlisî, Müsned, III, 214-215 (1750); Buhârî, "Nikâh", 43; Ebû Davûd, "Nikâh", 26 ve diğerleri.

114 Ahmed b. Hanbel, Müsned, VI, 433-434 (27444); Ebû Davûd, "Talâk",18; Nesâî, "Talâk", 34

115 Ahmed b. Hanbel, Müsned, VI, 373 (27100), Tayâlisî, Müsned, III, 214-215 (1750); Hâkim en-Nîsâbûrî, Müstedrek, "Talâk", II, 209, "Ma'rifetü's-Sahâbe", III, 309, Taberânî, Mu'cemü'l-Evsat, II, 108 (1209).

116 Ümmü Eyyûb hakkında (Taberânî, Mu'cem, XXV, 136); Ümmü Süleym hakkında (Beyhakî, Sünen, "Talâk", VII, 323). 
Ahmed b. Hanbel ve Tayâlisî Müsnedlerinde Rivayeti Bulunan Kadın Sahabîlerin... getirilmiştir. ${ }^{117}$ Eşi kendisine tokat atan kadın da şikâyetiyle Allah Resûlü'ne gelmiş, eşi çağırılarak olay sorgulanmıştır. ${ }^{118}$ Kadınların dinî hassasiyetle eşlerine yaptıkları uyarıların, İslam'da öne geçip eşlerine vesile olmalarının, ${ }^{119}$ dinen yasak veya yanlış olduğunu düşündükleri meseleyi Resûlullah'a sormadan rahat etmemelerinin ${ }^{120}$ örnekleri de vardır.

Kadınlardan gelen rivayetlerde sordukları sorular, önemli yer tutar. Hz. Âişe'nin olaylar karşısında sorgulayıcı yaklaşımının ve Allah Resûlü'nün de bunu desteklemesinin birçok örneği mevcuttur. ${ }^{121} \mathrm{O}$, bu desteği tüm kadınlara sunmuştur. Kendi özel sıkıntıları hakkında, öğrenmek istedikleri dinî meselelerde ona soru sorup cevap almayan, çocukları için hayır dua istemek gibi bir talebine karş1lik bulmayan yoktur.

Fıkhi konular da rivayeti bulunan birçok kadın vardır. İhtilaflı meselelerde görüşlerinin alınması, bu görüşlere göre hüküm verilmesi, kadınlara ait özel hâllerin bilgisinin onlardan gelmesi, uğradıkları haksızlıkları kabul etmeyip itiraz etmeleri, kimi zaman çıkarlarını koruyacak siyasi çözümler üretmeleri fıkhi kaideleri bildiklerini göstermektedir. Kimi kadınlar fıkhi rivayetleriyle tanınır.

Kur'an ilimlerinde; kadınlar hakkındaki ayetlerin sebebi nüzulleri, kıraat farklılıkları, Kur'an lafızlarının manaları hakkında rivayetleri vardır. Kadınlardan kimisi de Kur'an bilgisiyle öne çıkar.

Siyaset, içinde oldukları ve hakkında bilgi aktardıkları bir alandır. Hz. Peygamber, onların biatlerini alarak ve verdikleri emanı geçerli kabul ederek siyasi haklarını tanımıştır. Onlar da Müslüman toplumun yaşadığı siyasi çalkantılara katılmışlar, görüşlerini açıklayıp savunmuşlardır.

İkinci başlıkta örnekleri geçtiği üzere; hemşire-ebe olduğu için tıbbî mevzu, cenaze yıkama işlerinde görev aldığı için cenaze yıkanması, dua öğrenmeyi önemsediği için dua, tavsiye-uyarılara dikkat

117 Nesâî, "Talâk", 54; Hâkim en-Nîsâbûrî, Müstedrek, "Talâk", II, 209.

118 Ahmed b. Hanbel, Müsned, VI, 272, (26339), 410-411, (27319); Ebû Davûd, "Talâk", 17.

119 İbn Sa'd, Tabakât, VIII, 312-314; İbn Abdilber, İstîâb, IV, 488-489; Zehebî, Siyer, II, 340.

120 Ahmed b. Hanbel, VI, 305 (26601), 310 (26643); Taberânî, Mu'cem, XXIV, 338

121 Ahmed b. Hanbel, Müsned, VI, 35; 174, 281; 175, 187, 239; Tayâlisî, Müsned, III, 28 (1633); Müslim," İmân", 91; "Salât", 42; Buhârî, "Tefsir", 108; "Hibe", 16; Ebû Davûd, "Edeb", 132 ve diğgerleri. 
kesildiği için tavsiye-uyarı konularını içeren rivayetleri öne çıkan kadın sahabîler de vardır.

Tek rivayeti bulunan kadın sahabeden gelen Allah Resûlü'nün kadınları koruması, yakın davranışı, soru ve sorunlarına cevap verişi hakkında rivayetler; kadınlara yönelik tavrını tüm kesimlere, yakın-uzak çevre, asil-halk-cariye, yaydığını ispatlar.

\section{Kadın Sahabîlerin Rivayetlerinde Görülen Hz. Peygamberin Kadınlara Davranış Şekli}

Resûlullah'ın kadınlara davranışındaki incelik, onların hatıralarıyla ayrıntılı bilinir. Amcası Hz. Hamza'nın eşi Havle'nin önüne koyduğu sıcak yemekten eli yanınca "Ah!" etmiş ardından o incinmesin, suçlu hissetmesin diye "İnsan, parmakları üşüse de inler, yansa da inler!" diyerek ah etmesinin sebebini kendisine bağlamıştır ve yengesi ona Havzı'nı sorduğunda "Oraya gelmesine en çok sevineceklerim kavmindir" diyerek onu ve kavmini övmüştür. ${ }^{122}$ Koyun kesen amcakızı Dubâ'a bnt. Zübeyr'den pay istemiş; koyunun boynu dışında bir parçası kalmadığını, onu da Allah Resûlü'ne göndermekten utandığı cevabına "Boyun koyunun değerli yeridir. Onun en faydalı yeridir, zarar vermekten en uzağıdır" karşılığını vererek gönlünü hoş etmiş ve o parçayı göndermesini söylemiştir. ${ }^{123} \mathrm{Bir}$ başka amcakızı, Ümmü Hânî bnt. Ebî Tâlib'in evine geldiği bir gün "Yiyecek bir şeyiniz var mı?" diye sorduğunda "Biraz ekmek kırıntısı ve sirke hariç yok" deyince "Getir onu. Sirke bulunan kişinin evi, fakir değildir" 124 cevabıyla ev sahibini rahatlatmış, ikramının değerini arttırmıştır. Kadınlarla karşılıklı hastalık için veya günlük ziyarette bulunmuş, ${ }^{125}$ selamlaşmış, ${ }^{126}$ ikramda bulunmuş, ${ }^{127}$ sohbet etmiş, borç ödemekte yardımlaşmış, ${ }^{128}$ onlara yönelik övgü ve sevgi ifadeleri kullanmıştır. Düğünde gelinin yanı başına oturmuş, ${ }^{129}$

\footnotetext{
122 Ahmed b. Hanbel, Müsned, VI, 410 (27316).

123 Ahmed b. Hanbel, Müsned, VI, 361 (27031).

124 Tirmizî, "Et'ime", 35.

125 Ahmed b. Hanbel, Müsned, VI, 339 (26876); 364 (27051-27053; Ebû Davûd, "Trb", 2; Tirmizî, "Tıb",1; Müslim, "Fezâil", 3 İbn Abdilber, İstîâb, IV, 519 ve diğgerleri.

126 Ebû Davûd, "Edeb", 148; İbn Mâce, "Edeb", 14; İbn Sa'd, Tabakât, VIII, 319.

127 Ahmed b. Hanbel, Müsned, VI, 452 (2756); Nesâî, "Eşrîbe", 58; İbn Ebî Âsım, elÂhâd ve'l-Mesânî, V, 466 (3120) ve diğerleri.

128 Ahmed b. Hanbel, Müsned, VI, 364, (27054-27055); 378, (27124); 410, (27317); Taberânî, $M u^{\prime}$ cemü'l-Evsât, 6: 16, (5025).

129 Ahmed b. Hanbel, Müsned, VI, 359, (27021); 360, (27027); Buhârî, "Meğâzî", 12; Ebû Dâvûd, "Edeb", 59.
} 
Ahmed b. Hanbel ve Tayâlisî Müsned'lerinde Rivayeti Bulunan Kadın Sahabîlerin... yaptığ1 yemeği ikram eden kadına kolye hediye etmiş, ${ }^{130}$ yük taşıyan baldızına terekesine bindirmeyi teklif etmiştir. ${ }^{131}$ Birçok örnekle kadınlara nasıl yumuşak ve düşünceli davranılacağını göstermiştir.

Allah Resûlü, boşanma veya dul kalma durumundaki kadınların dünürlerinin kimler olduğuyla ilgilenip evlilikleri için tavsiyelerde bulunmuştur. ${ }^{132}$ Mescide kadınların gelmesine izin verilmesini istemiş, önce onlar çıksın diye namazdan sonra beklemiş, kendi eşlerini perdeyle ayrılmış bölümlerle mescide açılan odalara yerleştirmiş, bayram namazına kadınların da katılmalarını -hayızlılar (duaya iştirak için), elbise bulamayıp komşusundan ödünç alanlar da dahil- istemiştir. Sordukları her soruya cevap vermiş, sefer veya yolculuğunda eşlerinden mutlaka bir-ikisini yanına almış, rahat yolculuk edebilsinler diye yavaş gitmiş, eşlerinin şahsi ihtiyaçları için gerektiğinde kervanı bekletmiştir. Eşlerinin kıskançlıkla sergiledikleri davranışlara anlayışla yaklaşmış, onları en güzel şekilde uyarmış, gün içinde onlarla vakit geçirmiş, yanlış davranışlarında asla şahsiyetlerine eleştiri getirmeden yapılan davranışı kınamış, ${ }^{133}$ İslam'ın prensiplerine uymayan davranışa karşı, yapanın kişiliğine hakaret etmeden, tavır almıştır. ${ }^{134}$ Kadınları incitmemek için onlara karşı sözlerinde yumuşaklığı, gönül almayı, hediyelerine üstünüyle karşılık vermeyi şiar edinmiştir. Onların sözlerine değer vermiş, verdikleri emanı kabul etmiş, ${ }^{135}$ biatlerini almış ve bir kadının sözüyle yazmayı düşündüğü fermandan vaz geçmiştir. ${ }^{136}$

Mağdur olarak ona gelen hiçbir kadını geri çevirmemiştir. Hudeybiye Antlaşması gereğince hicret eden kadının müşrik yakınlarına teslim edilmesini, kadınların teslim edilmeyeceğiyle ilgili ayet

\footnotetext{
130 Ahmed b. Hanbel, Müsned, VI, s359, (27020, 27023).

131 Ahmed b. Hanbel, Müsned, VI, 347, (26937); 352, (26972); Buhârî, "Nikâh", 108; Müslim, "Selâm", 14.

132 Ahmed b. Hanbel, Müsned, VI, 373-374, (27100-27101); 411-412, (27323); 412, (27326); 413, (27431); Tayâlisî, Müsned, III, 214-215, (1750); Müslim, "Talâk", 6; Tirmizî, "Nikâh", 38. İbn Sa'd, Tabakât, c. III, s. 162; Taberânî, Mu'cemü'l-Evsat, II, 108, (1209).

133 Ahmed b. Hanbel, Müsned, VI, 138 (25074), Taberânî, Mu'cem, XXIV, 35.

134 Ahmed b. Hanbel, Müsned, VI, 132 (25002).

135 Ahmed b. Hanbel, Müsned, VI, 341, (26892, 26889); 342, (26896); 343, (26903, 26906-26908); 423, (27379-27380); 425, (27388, 27392); Müslim, "Hayz" 16; Ebû Davûd, "Tetavvu' ", 12.

136 Ebû Dâvûd, "Haraç", 36.
} 
inmeden önce, kabul etmemiştir. ${ }^{137}$ Eşleri ölen kadınların mirasçıları tarafından evlerinden çıkarılmalarını yasaklamıştır. ${ }^{138}$ Annenin şikâyeti üzerine $\mathrm{k}_{1 z}$ çocuklarının mirastan mahrum edilmesini ve zorla evlendirilmesini yasaklayan ferman yazdırmıştır. ${ }^{139}$ Velisinin zoruyla evlendirilen kadının nikâhını geçersiz saymıştır. ${ }^{140}$ Boşanma talep eden kadınların boşanmasını sağlamıştır. ${ }^{141}$ Cariye bir kadının, oğlunun babası olan sahibi öldüğünde, sahibinin borçları için satılmasına engel olmuştur. ${ }^{142}$ Yaşadığı dönemde Allah Resûlü, Yemen'deki bir kadın için bile haksızlığa uğradığında ümittir. ${ }^{143}$ Elbette $\mathrm{O}$, mazlumun ümidini boşa çıkarmamış, haksızlığı ortadan kaldırmıştır.

\section{Sonuç}

Kadın sahabîlerin rivayetlerini değerlendirmek amacıyla yapılan bu çalışmada, öncelikle rivayetlerinin sayısal değeri üzerinde durulmaktadır. Müsned türü eserlerde bu değer genelde, eserlerin \%10'luk kısmına karşılık gelmektedir. Eserin tümüne göre bu oran düşük olsa da zamanla kadınların hadis ilmine görünür katkısının bu oranda kalamadığı, gittikçe düştüğü unutulmamalıdır. Tekrarlarla artan rivayet sayılarının gerçek değerini görebilmek, tekrarsız rivayet sayılarını belirlemekle mümkündür.

Seçilen iki kaynakta yer alan 105 kadın sahabenin 3 bin 800 rivayetinin tekrarsızda 1000 civarında olduğu ve dörtte üçe yakın tekrarın bulunduğu anlaşılmaktadır. Rivayet metinlerine bakıldığında, rivayetlerin tekrarının artmasında etkili olan özelliklerin; rivayetin sahabe döneminde tartışmalı olan, hakkında farklı görüşler bulunan bir konuya dair oluşu ya da toplum tarafından yadırganan bir davranışı doğrulaması ve genel kanaat veya uygulamadan farklı bilgi

137 İbn Sa'd, Tabakât, VIII, 183; Huriye Martı, “Ümmü Külsûm bint Ukbe”, DİA (Ankara: TDV Yayınları, 2012), c. XLII, 325.

138 Ahmed b. Hanbel, Müsned, VI, 363, (27049-27050); Ebû Davûd, "Harâç", 37.

139 Taberânî, Mu'cem, 25: 7-11; Rıza Savaş, “Hz. Peygamber'in Bir Kadın Konuğu: Kayle bnt. Mahrama", Dokuz Eylül Üniversitesi IIlahiyat Fakültesi Dergisi 12 (1999): 39-46.

140 Ahmed b. Hanbel, Müsned, VI, 328, (26786, 26787-26789); 328-329, (26790-26791); Buhârî, "Nikâh", 43; Ebû Davûd, "Nikâh", 26.

141 Nesâî, "Talâk", 54. Hâkim en-Nîsâbûrî, Müstedrek, "Talâk", II, 209. Ahmed b. Hanbel, Müsned, V, 433-434, (27444); Ebû Davûd, "Talâk,18; Nesâ̂̂, "Talâk", 34.

142 Ahmed b. Hanbel, Müsned, VI, 360, (27029); Ebû Dâvûd, "Itk", 8.

143 Taberânî, Mu'cem, XXV, 7-11; Rıza Savaş, "Hz. Peygamber'in Bir Kadın Konuğu: Kayle bnt. Mahrama", 39-46. 
Ahmed b. Hanbel ve Tayâlisî Müsned'lerinde Rivayeti Bulunan Kadın Sahabîlerin...

içermesi ya da dinî bir meseleyi öğrenme isteğini karşılaması olduğu görülmektedir. Anlaşılan sahabe dönemin de günümüzde olduğu gibi toplumda ilgi ve ihtiyaç duyulan konulara dair rivayetler araştırılmış, böylelikle ilgili rivayetlerin tekrarı artmıştır.

Çalışma kapsamındaki 105 kadın sahabîden, beş ve üzeri sayıda rivayeti bulunanlar 32, dört ile iki arası rivayeti olanlar 22 kişidir. Kalan 51 kadın sahabenin, tek rivayeti mevcuttur. Rivayet sayısı ondan fazla olan kişiler; hicrî 20'lerden sonra vefat etme, Hz. Peygamber'in yakın çevresine dahil olma ve ailesinden hadis ilmiyle meşhur râvileri bulunma özelliklerinin üçüne birden sahiptir. Aynı zamanda içlerinden dört kişi hariç; Esmâ bnt. Yezîd, Ümmü Atıyye, Ümmü Süleym ve Şifâ bnt. Abdullah, hepsi Hz. Peygamber'in eş, akraba, hısım ve azadlıları arasındandır. Tek rivayeti olanların rivayetlerinden soru ve sorunları Allah Resûlü'ne ulaştırabildikleri, cariye dahi olsalar haksızlığa uğramalarına engel olunduğu anlaşılmaktadır. Kadın sahabîlerin râvilerinde erkekler ve akrabalar çoğunluktadır ve kadın râvilerinin çoğu hakkında bilgi olmadığından meçhuldür. Neredeyse sadece rivayeti ile tanınan kadınların, râvilerinin meçhul olması ise daha da yaygındır. Doğal olan bu durum, kadın sahabîlerden hadisi rivayet eden tâbiûnun meçhul olmasının rivayeti zayıf veya merdûd kabul etmek için yeterli görülmemesi gerektiği kanaatini oluşturmaktadır.

Kadın sahabîlerin rivayetlerinin konuları çeşitlidir. Hz. Peygamber'in eş ve akrabalarının rivayetlerinde ibadetler ve temizlik konuları başta gelirken diğer kadınların rivayetlerinde emir-yasaktavsiyeler konusu birinci sıradadır. Buna dayanarak Hz. Peygamber' in kadınlara dünya ve ahiretlerini güzelleştirecek tavsiyeler verdiği, belki de bir kez karşılaşıp konuştuğu bir kadına güzel öğütte bulunma fırsatını değerlendirdiği söylenebilir. Fıkıh, nikah, kadınlara ait özel haller, gayb ve siyaset kadın sahabe rivayetlerinin diğer önemli konu başlıklarıdır ve kadın sahabenin sosyal-fikri-iktisadi hayatın içinde olduklarını yansıtmaktadır. Aile hayatına dair konular hakkındaki bilgiler ise çoğunlukla Hz. Peygamber'in eş ve akrabalarından gelmektedir.

Kadınların Asr-ı saâdette hemşirelik-ebelik, eğitim, el sanatları gibi sahalarda faaliyet gösterdikleri; mescidin müdavimi oldukları, savaşlarda geri hizmet, hatta kabiliyetlilerinin ön saflarda savunma yürüttükleri, ganimet ve feyden pay aldıkları; Müslüman oldukları 
için işkenceye, hicretin zorluklarına katlandıkları; yaşadıkları hayatın ince detayları kadın sahabenin anlattıklarıyla bilinir.

Kadınlara incelikli, değer verir, kıymet bilir davranışın nasıl olacağ1 kadın sahabîlerin rivayetlerde anlatılan Allah Resûlü'nün örnek davranışlarıyla hayat bulur. Görünce selam vermek, selamını almak, hallerinden haberdar olup ilgilenmek, haliyle ilgilenmelerine fırsat vermek, en değersiz görülebilecek hediye veya ikramı en değerli göstererek kabul etmek, incitmemek, ziyaretleşmek, anlattığını dinlemek, tavsiyede bulunmak, tavsiyesini kabul etmek, sorusunu cevaplamak, hediyeleşmek, hediyeyi öncesinde iltifat ederek sunmak, ihtiyaçlarını karşılamak, ihtiyacı olunca yardım istemek, dua etmek, dua öğretmek, yardımına koşmak, yardımını kabul etmek. Sayılan davranışlar Resûlullah'ın kadınlara değer verdiğini gösterme şekillerindendir. Arap toplumunda kadına değer verilmediği göz önüne alınırsa sünnette ortaya konulup kadın sahabe rivayetleriyle ayrıntılı öğrenilebilen bu örnek davranışların önemi daha iyi anlaşılır.

Hz. Peygamber'in örnekliğinde yetişen sahabe, ihtilaflı meselelerde kadın sahabeye danışmış, onların verdiği fetvaları araştırmışlardır. Hz. Peygamberin eşlerinin söylediklerini, özellikle aile ve mahrem hayata dair fetvalarda, üstün tutmuşlar; kadınlar yanlış fetvalarını düzelttiğinde hatalı olabileceklerini itiraf etmişlerdir.

Kadın sahabîlerin rivayetleri olmasaydı; Hz. Peygamber'in kadınlara karşı örnek davranışlarının öğrenilmesinde, dönemin yaşantısının anlaşılmasında, bir kısım dinî ve kadınlara dair hükümlerin bilinmesinde, eksiklik ve yanlış anlaşılma kaçınılmaz olurdu. Sonuçta bu rivayetlerin keyfiyette taşıdı̆̆ı önemin, kemmiyetlerinden fazla olduğunu güvenle söyleyebiliriz.

\section{Kaynakça}

Ağırakça Şahyar, Ayşe Esra. Seyahat ve Rivayetleriyle Hanım Sahabîler. İstanbul: Akdem Yayınları, 2015.

Ahmed b. Hanbel, Ebû Abdullah Ahmed b. Muhammed b. Hanbel eşŞeybânî el-Mervezî. el-Kütübü's-Sitte ve Şürûhuha: Müsnedu Ahmed b. Hanbel. 20-23 Cilt. İstanbul: Çağrı Yayınları, 2. baskı, 1982.

Ahmed b. Hanbel, Ebû Abdullah Ahmed b. Muhammed b. Hanbel eşŞeybânî. Kitâbü Fezâilü's-Sahâbe. 2 cilt. Mekke, Camiatü Ümmü'lKurâ, 1983.

Ateş, Fatma. Hz. Peygamber'in Hanımlarından Hafsa'nın Hayatı, Kişiliği ve İslâm Tarihi'ndeki Yeri. Urfa: Harran Üniversitesi, 2007. 
Ahmed b. Hanbel ve Tayâlisî Müsnedlerinde Rivayeti Bulunan Kađın Sahabîlerin...

Ay, Abdurrahman. Hz. Peygamber'in Hanımı Ümmü Seleme. İstanbul: Marmara Üniversitesi, 2003.

Aydemir, Halis. "Hadis Rivayet Sisteminde Râvi Modelleri”. Hadis Tetkikleri Dergisi 5/1 (2007): 85-100.

Başar, Serpil. “Ümmü Seleme'nin Tefsir Rivayetlerinin Değerlendirilmesi”. Dokuz Eylül Üniversitesi İlahiyat Fakültesi Dergisi 2/36. (2012): 427-448.

Bolelli, Nusret. Kadınların Hadis İlmindeki Yeri. İstanbul: Marrmara Üniversitesi İlahiyat Fakültesi Yayınları, 1998.

Budak, Ali. "Muhtevaları Açısından Ezvâc-1 Tâhirât'ın Rivayetleri", Dicle Üniversitesi İlahiyat Fakültesi Dergisi 13/2 (2011): 41-85.

Buhârî, Ebû Abdullah Muhammed b. İsmâil b. İbrâhim. Sahîh-i Buhârî. 4 Ciltte 8 Cilt. İstanbul: Mektebetü'l-İslâmî, 1979.

Ebû Dâvûd, Süleyman b. Eş'as b. İshâk el-Ezdî Ebû Dâvûd es-Sicistânî. Sünenu Eb̂̂ Dâvûd. thk. İzzet Ubeyd ed-De'as vd. 5 Cilt. Humus: Muhammed Ali es-Seyyid, 1969.

Ebû Ya'lâ el-Mevsılî, Ahmed b. Ali b. Müsennâ. Müsnedu Eb̂̂ Ya'lâ el-Mevsılî. thk. Mustafa Abdülkadir Atâ. 7 Cilt. Beyrut: Dâru'l-Kütübi'l-İlmiyye, 1998.

Emîn, Hamza Muhammed. Cühûdü'l-mer'e fî̀ rivâyeti'l-hadîsi'l-nebeviyyi'lşerîfi fí'l-kurûni'l-selâseti'l-ûlâ. Ürdün: Câmi'atu Âl el-Beyt, 1999.

Eren, Mehmet. “Kadınların Hadis İlmine Katkıları”. AÜIFD. 44/1 (2003): 83110

Fahreddîn er-Râzî, Ebû Abdullah Fahreddîn Muhammed b. Ömer. etTefsîru'l-kebîr: Mefâtîhu'l-gayb. 8 Ciltte 16 Cilt. Beyrut: Dâru ihyâi'ttürâsi'l-Arabî, 1934.

Güşen, Seyit Ali. "Sahabe Mesleklerinin Hadis Rivayetlerine Etkisi". Dinbilimleri Akademik Araştırma Dergisi 19/2 (Eylül 2019): 339-364.

Gümrükçüoğlu, Süleyman. Hz. Hafsa'nın Hayatı ve Rivayetleri. İstanbul: Marmara Üniversitesi, 2004.

Hâkim en-Nîsâbûrî, Ebû Abdullah İbnü'l-Beyyi Muhammed. el-Müstedrek ale's-Sahîhayn. thk. Şemsüddîn Ebî Abdullah. 4 Cilt. Haydarâbâd: Dâru'l-kütübi'l-ilmiyye, 1915.

Hamîd, Afâf Abdülgafûr. "Cühûdü'l-mer'e fî neşr'il-hadîsi ve ulûmuhu". Mecelletü Câmi'a'ti'l-ummü'l-kurâ li ulûmi'l-şer'iyye 19/42 (2007): 230270.

Hasenî, Âmine Emizyan. Ümmü Seleme. 2 Cilt. Rabât: Vizâretü'l-evkaf ve'şşuûni'l-İslâmiyye, 1998.

Hıfnî, Abdülmün'im. Mevsû'atu ümmi'l-Mü'minîn Âişe binti Ebî Bekr. Kahire: Mektebetü Medbulî, 2003.

İbnü'l-Cevzî, Ebü'l-Ferec Cemâlüddîn Abdurrahmân b. Alî b. Muhammed Bağdâdî. Kitâbü'l-Mevzûât. thk. Abdurrahman Muhammed Osman. 3 Cilt. Beyrut: Dâru'l-Fikr, 2. baskı, 1983.

İbn Ebî Şeybe, Ebû Bekr Abdullah b. Muhammed b. İbrâhim. el-Musannef. thk. Muhammed Avvâme. 24 Cilt. Cidde: Dâru'l-kıble, 2006. 
İbn Hacer, Ebü'l-Fazl Şihâbüddîn Ahmed b. Alî b. Muhammed b. Hacer elAskalânî. Tehzîbu't-Tehzîb. 6 Cilt. Beyrut: Dâru ihyâi't-türâsi'l-Arabî, 1991.

İbn Hacer, Ebü'l-Fazl Şihâbüddîn Ahmed b. Alî b. Muhammed b. Hacer elAskalânî. el-İsâbe fî temyîzi's-Sahâbe. 8 Cilt. Kahire: Mektebetü't-ticariyyeti'l-kübrâ, 1939.

İbn Hacer, Ebü'l-Fazl Şihâbüddîn Ahmed b. Alî b. Muhammed b. Hacer elAskalânî. Lisânü'l-mîzân, thk. Muhammed Abdurrahman Maraşli. 9 Cilt. Beyrut: Dâru ihyâi't-türâsi'l-Arabî, 1995

İbn Kesîr, Ebü'l-Fidâ İmâdüddîn İsmâil b. Ömer. Tefsîru'l-Kur'âni'l-azîm: Tefsîru İbn Kesîr. 7 Cilt. Beyrut: Dâru'l-Endelüs, 1966.

İbn Sa'd, Ebû Abdullah Muhammed b. Sa'd b. Meni' ez-Zührî. et-Tabakâtu'lKübrâ. 8 Cilt. Beyrut: Dâru Sadır, 1968.

Îmân, Muhammed İsmâil. Merviyâtu men tüsemmeyne bi Esmâ' mine'sSahâbiyyât. Suudi Arabistan: Câmi'atu el-Meliki Su'ûd, 2004.

İ. Muhammed Cemel. Câmi'u mesânidi'n-nisâ' ve zikrihinne ve ahvâlihinne. Kahire: Dâru'l-Misriyyeti'l-Lübnaniyye, 1992.

Kandemir, M. Yaşar. "Hanımların Dilinden Hz. Peygamber". Tartışmalı İlm̂̂ Toplantılar Dizisi Hz. Peygamber ve Aile Hayatı. ed. Ali Özek vd. İlmi Neşriyat: İstanbul, ts., 89-112.

Kandemir, M. Yaşar. "el-Müsned". DIA. c. XXXII, s. 104.Ankara: TDV Yayınları, 2006.

Kandemir, M. Yaşar. “Ümmü Süleym”. DİA. c. XLII, s. 330-331.Ankara: TDV Yayınları, 2012.

Karataş, Mustafa. "Hadis Sayım Metodlarının Hadislerin Sayısına Etkisi". ILLAM Araştırma Dergisi 3/2 (1998): 51-72.

Kurt, Hatice. Sahabî Hanımlar ve Hadis İlmi. Sakarya: Sakarya Üniversitesi, 2002.

Kuzudişli, Bekir. Hadis Rivâyetinde Aile İsnadları. İstanbul: İşaret Yayınları, 2007.

Martı, Huriye. "Ümmü Külsûm bint Ukbe". DİA. c. XLII, s. 325. Ankara: TDV Yayınları, 2012.

Müslim, Ebü'l-Hüseyin el-Kuşeyrî en-Nîsâbûrî Müslim b. el-Haccâc. elMüsnedü's-sahîh el-muhtasar mine's-sünen bi-nakli'l-adl ani'l-adli ilâ Resûlillah. thk. Ebû Kuteybe Nazar Muhammed el-Faryabî. 8 Cilt. Riyad: Dâru't-Talia, 2006.

Nadwi, Mohammad Akram. al-Muhaddithat: The Women Scholars in Islam. Oxford: Interface, 2007.

Nesaî, Ebû Abdurrahman Ahmed b. Ali b. Şuayb. Sünenü'n-Nesâ̂. thk. Abdülfettâh Ebû Gudde. 9 Cilt. Beyrut: Dârü'l-beşairi'l-İslâmiyye, 3. Baskı, 1988.

Okiç, M. Tayyib. İslâmiyette Kadın Öğretimi. Ankara: DİB Yayınları, 1984.

Öztürk, Kadir. Esmâ Bnt. Yezîd'in Hayatı ve Rivayetleri. İstanbul: Marmara Üniversitesi, 2010. 
Ahmed b. Hanbel ve Tayâlisî Müsnedlerinde Rivayeti Bulunan Kadın Sahabîlerin...

Peköz, Emine. Hz. Peygamber'in Hanımlarından Ümmü Habîbe'nin Hayatı, Kişiliği ve İslâm Tarihi'ndeki Yeri. Urfa: Harran Üniversitesi, 2012.

Savaş, Rıza. “Hz. Peygamber'in Bir Kadın Konuğu: Kayle bnt. Mahrama”, Dokuz Eylül Üniversitesi İlahiyat Fakültesi Dergisi 12 (1999): 39-46.

Sayeed, Asma. Women and the Transmission of Religious Knowledge in Islam. Cambridge: Cambridge University Press, 2013.

Söylemez, M. Mahfuz. “Hz. Peygamber' in Bir Günü Üzerine”, İslâmî İlimler Dergisi 1/1 (2006): 69-84.

Şener, Mehmet. "Kuşluk Namazı". DİA. c. XXVI, s. 475. Ankara: TDV Yayınları, 2002.

Taberânî, Ebû Kâsım Süleyman b. Ahmed b. Eyyûb el-Lahmî. el-Mu'cemü'lkebîr. thk. Hamdi Abdülmecid Selefî. 25 Cilt. Beyrut: Dâru ihyai'ltürâsi'l-Arabî, 2. baskı, 1984.

Taberânî, Ebû Kâsım Süleyman b. Ahmed b. Eyyûb el-Lahmî. el-Mu'cemü'lKebîr. thk. Ebû Muhammed Esyûtî. 11 Cilt. Beyrut, Dâru'l-Kütübi'lİlmiyye, 2007.

Taberânî, Ebû Kâsım Süleyman b. Ahmed b. Eyyûb el-Lahmî. el-Mu'cemü'levsât, thk. Mahmûd b. Ahmed et-Tahhân. 10 Cilt. Riyad: Mektebetü'l-Maârif, 1985.

Tirmizî, Ebû Îsâ Muhammed b. Îsâ b. Sevre. Sünenu't-Tirmizî. thk. İbrâhim Atve İyâz. 5 Cilt. Kahire: Mustafa el-Babî el-Halebî, 2. baskı, 1975.

Topgül, Mürvet Nur. Esmâ Bnt. Ebi Bekr ve Hadis İmindeki Yeri. Çanakkale: Çanakkale Onsekiz Mart Üniversitesi, 2011.

Tüfekçioğlu, Zekeriyya. Hadis Edebiyatında Müsnedler (Hicrî İlk Üç Asır). İstanbul: Marmara Üniversitesi, 2012.

Uraler, Aynur. Peygamberimizin Hanımı Ümmü Habîbe ve Rivayet Ettiği Hadisler. İstanbul: Çamlıca Yayınları, 2010.

Aynur Uraler. "Muâze el-Adeviyye". DIA. c. XXX, s. 341. Ankara: TDV Yayınları, 2005.

Varlık Kotan, Sehal Deniz. Kadın Sahabîlerin Rivayetlerinin Değerlendirilmesi. Ankara: Ankara Üniversitesi, 2019.

Zerkeşî, Bedreddîn. el-İcâbe, Hz. Âişe'nin Sahabeye Yönelttiği Eleştiriler. çev. Bünyamin Erul. Ankara: Kitâbiyât Yayınları, 2002. 